\title{
Bioactive Peptides Against Fungal Biofilms
}

\section{Karen G. N. Oshiro ${ }^{1,2}$, Gisele Rodrigues ${ }^{3}$, Bruna Estéfani D. Monges², Marlon Henrique Cardoso ${ }^{2,3}$ and Octávio Luiz Franco 1,2,3*}

${ }^{1}$ Programa de Pós-Graduação em Patologia Molecular, Faculdade de Medicina, Universidade de Brasilia, Brasília, Brazil, ${ }^{2}$ S-Inova Biotech, Programa de Pós-Graduação em Biotecnologia, Universidade Católica Dom Bosco, Campo Grande, Brazil, ${ }^{3}$ Centro de Análises Proteômicas e Bioquímicas, Programa de Pós-Graduação em Ciências Genômicas e Biotecnologia, Universidade Católica de Brasília, Brasilia, Brazil

Infections caused by invasive fungal biofilms have been widely associated with high morbidity and mortality rates, mainly due to the advent of antibiotic resistance. Moreover, fungal biofilms impose an additional challenge, leading to multidrug resistance. This fact, along with the contamination of medical devices and the limited number of effective antifungal agents available on the market, demonstrates the importance of finding novel drug candidates targeting pathogenic fungal cells and biofilms. In this context, an alternative strategy is the use of antifungal peptides (AFPs) against fungal biofilms.

OPEN ACCESS

Edited by:

Jose F. Marcos,

Instituto de Agroquímica y Tecnología de Alimentos (IATA), Spain

Reviewed by: Anand K. Ramasubramanian, San Jose State University,

United States

Dilip Shah,

Donald Danforth Plant Science

Center, United States

*Correspondence:

Octávio Luiz Franco ocfranco@gmail.com

Specialty section:

This article was submitted to Fungi and Their Interactions,

a section of the journa

Frontiers in Microbiology

Received: 26 March 2019 Accepted: 04 September 2019 Published: 04 October 2019

Citation:

Oshiro KGN, Rodrigues G, Monges BED, Cardoso $\mathrm{MH}$ and Franco OL (2019) Bioactive Peptides Against Fungal Biofilms.

Front. Microbiol. 10:2169. doi: 10.3389/fmicb.2019.02169
AFPs are considered a group of bioactive molecules with broad-spectrum activities and multiple mechanisms of action that have been widely used as template molecules for drug design strategies aiming at greater specificity and biological efficacy. Among the AFP classes most studied in the context of fungal biofilms, defensins, cathelicidins and histatins have been described. AFPs can also act by preventing the formation of fungal biofilms and eradicating preformed biofilms through mechanisms associated with cell wall perturbation, inhibition of planktonic fungal cells' adhesion onto surfaces, gene regulation and generation of reactive oxygen species (ROS). Thus, considering the critical scenario imposed by fungal biofilms and associated infections and the application of AFPs as a possible treatment, this review will focus on the most effective AFPs described to date, with a core focus on antibiofilm peptides, as well as their efficacy in vivo, application on surfaces and proposed mechanisms of action.

Keywords: antifungal peptides, fungal infections, fungal biofilms, antimicrobial peptides, mechanisms of action

\section{INTRODUCTION}

Fungal infections are recurrent in the clinical environment and, annually, affect $\sim 25 \%$ of the general population worldwide, causing high morbidity and mortality rates (Brown et al., 2012; Gamaletsou et al., 2018). The indiscriminate use of broad-spectrum antibiotics, along with parenteral nutrition, permanent catheters, chemotherapy and radiotherapy, as well as immunosuppression in patients, are the most important predisposing factors for invasive fungal

Abbreviations: AFM, atomic force microscopy; AFPs, antifungal peptides; AMPs, antimicrobial peptides; BIC, biofilm inhibition concentration; BIC50, concentration required to reduce biofilm formation by 50\%; Csf, caspofungin; GlcCer, glucosylceramide; Mcf, micafungin; MFC, minimal fungicidal concentration; MIC, minimal inhibitory concentration; PI, phosphatidylinositol. 
infections (Lionakis and Levitz, 2018). Fungi are classified according to their morphologies, including yeasts (Cryptococcus spp.), fungi with branched hyphae (Aspergillus spp./Rhizopus spp.), as well as fungi with both morphologies (yeasts and pseudohyphas, as for Candida spp.), which have all been associated with fungal infections in humans (Brown et al., 2012; Lionakis and Levitz, 2018). In addition, fungal pathogens can also organize multicellular consortia, known as biofilms, which establish resistant communities on a variety of biotic and abiotic surfaces (Nett and Andes, 2015). Fungal adhesion to biotic and abiotic surfaces represents an initial stage by which fungi establish biofilms. Consequently, this cellular mechanism has been investigated as a potential target for antibiofilm therapies (Nett and Andes, 2015).

\section{Fungal Biofilms}

Apart from their planktonic development, microorganisms can also establish biofilms in nature, and these biofilms allow microbial cells to survive in the host environment and be dispersed to colonize new niches (Hall-Stoodley et al., 2004). Fungal biofilms are composed of adherent cells covered by an extracellular matrix. First, free-floating cells adhere to a substrate followed by the secretion of an extracellular matrix, which confers additional mechanical protection on the fungal colonies. The release of biofilm cells is a regulated process by which organisms can spread throughout the host and establish new sites of infection (Nett et al., 2010; Uppuluri et al., 2010).

Studies have shown that biofilm-constituting cells usually present a different phenotype from that presented by planktonic cells. Among these differences, the elaborate architecture of biofilms has been highlighted as an additional challenge in the treatment of patients with systemic infections, mainly due to fungi's increased resistance to conventional antibiotics and lower performance of the host immune system (Gulati and Nobile, 2016). Medical devices, including catheters and artificial heart valves, are in constant contact with body fluids, facilitating glycoprotein substrate deposition and favoring fungal cell adhesion, followed by their colonization and biofilm formation (Giles et al., 2018). Biofilm formation has been well described in Candida albicans, the most common fungal pathogen in the hospital setting (Douglas, 2002). C. albicans biofilms are composed of yeast and hyphalic cells, both of which are necessary for biofilm formation on biotic and abiotic surfaces (Dongari-Bagtzoglou et al., 2009; Harriott et al., 2010). Moreover, Aspergillosis and Cryptococcus neoformans biofilms are among the major causes of nosocomial infections caused by fungi (Ajesh and Sreejith, 2012; Kaur and Singh, 2013).

\section{Overview on Antifungal Peptides (AFPs)}

Currently, antifungal therapies are scarce and include only four chemical classes of antifungal agents, namely polyenes, triazoles, echinocandins and flucytosine (Chowdhary et al., 2017). Moreover, the misuse of antifungal agents over the last two decades has contributed to antifungal resistance development (Perlin et al., 2017). Fungal resistance emergence has important clinical implications, as it limits the already small arsenal of antifungal agents, raising the idea of a "post-antifungal" era
(Chowdhary et al., 2017). Therefore, an alternative is the use of AFPs against fungal infections and biofilms (Matejuk et al., 2010). AFPs have been tested as promising therapeutic agents for biofilm-related infections (Di Luca et al., 2014). In this context, AFPs have been considered a bioactive molecule group with broad-spectrum activities and multiple mechanisms of action. The search for AFPs capable of acting on fungal biofilms with lower toxic effects on mammalian cells either alone or in combination with conventional antibiotics has been the subject of diverse studies (Fjell et al., 2012). Although biofilm-active AFPs have not been achieved in clinical and commercial use, the development, design and optimization of such molecules remain as an alternative treatment (Duncan and O'Neil, 2013).

Antifungal peptides are structurally diverse. Moreover, AFPs comprise amphipathic molecules capable of interacting with biological membranes (De Lucca and Walsh, 1999; Faruck et al., 2016; Rautenbach et al., 2016). In the past decade, an increasing number of works have reported AFPs capable of either inhibiting fungal biofilm formation or eradicating preformed biofilms, as well as some AFPs with both inhibitory and eradication properties (Matejuk et al., 2010; Delattin et al., 2017). Most AFPs display their biological activities through membrane-associated mechanisms of action. When compared to other eukaryotic cells (e.g., mammalian cells), fungal membranes present few differences, including sphingolipid composition, PI content and the presence of ergosterol as the main sterol (Rautenbach et al., 2016). These differences, along with specific targets in the fungal pathogen, including fungal proteins, mannosyldiinositol phosphorylceramide and GlcCer, provide useful information for the generation of selective AFPs, avoiding toxicity toward human cells (Rautenbach et al., 2016). In this context, this review will focus on the therapeutic potential of AFPs, highlighting the most effective AFPs described to date, with a core focus on antibiofilm properties. Finally, we will explore the application of AFPs and their proposed antibiofilm mechanisms of action.

\section{PEPTIDES WITH DELETERIOUS ACTIVITY TOWARD FUNGAL BIOFILMS}

\section{Defensin-Like Peptides}

Defensins comprise AFPs isolated from various organisms, including plants and mammals (Cools et al., 2017a). Structurally, defensins are organized in an $\alpha \beta$ motif, generally with an $\alpha$-helix and a triple-stranded antiparallel $\beta$-sheet, which is stabilized by disulfide bonds that ensure high stability, thus retaining their functions under extreme conditions by avoiding/decreasing degradation (Shafee et al., 2016). Many defensins share the CS $\alpha \beta$ motif, including plants, fungi and invertebrates. Therefore, the following subsections will address the structural characteristics, activity and mechanism of action of plant defensins, $\alpha$-defensins and $\beta$-defensins on fungal biofilms.

\section{Plant Defensins}

Plant defensins are cationic and have 45-54 amino acids in length. These peptides have typically been isolated from seeds, but can also be found in other plant tissues including leaves, 


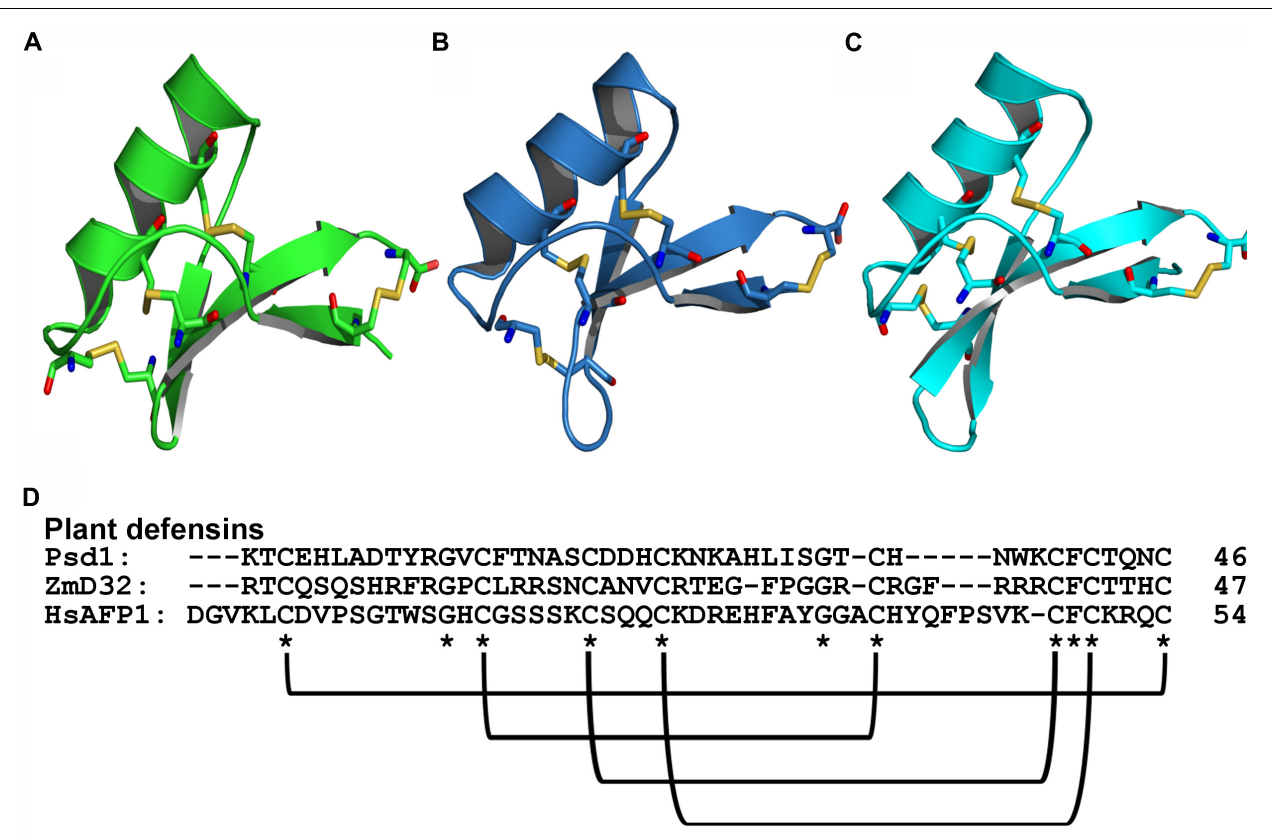

E

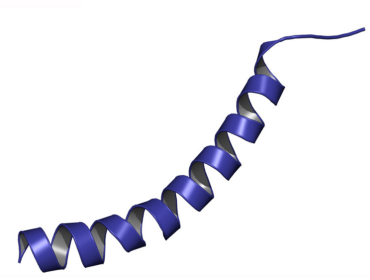

$\mathbf{F}$

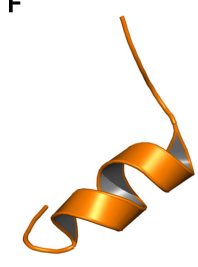

FIGURE 1 | Tridimensional structure of AFPs with antibiofilm activity against fungi. (A) Psd1 - PDB: 1JKZ in green; (B) ZmD32 - PDB: 6DMZ in blue; (C) HsAFP1 PDB: 2N2Q in cyan; (D) Sequence alignment of plant defensins showing the conserved regions and disulfide bonds; (E) LL-37 - PDB: 2K60 in purple; (F) BMAP-28 - PDB: 2NDC in orange; Disulfide bonds are highlighted as yellow sticks, oxygen atoms are in red and nitrogen atoms are in blue.

flowers, roots and stems (Lay and Anderson, 2005). Most of the plant defensins identified so far have eight cysteine residues that favor structural stability by the formation of four disulfide bonds. In addition, structural studies have shown that plant defensins comprise a triple $\beta$-sheet with a parallel helix (Thomma et al., 2002) (Figure 1). Regarding their biological properties, plant defensins have shown activity against bacteria (Sathoff and Samac, 2019) and fungi, both in their planktonic and biofilm modes of growth (Vriens et al., 2016; Gonçalves et al., 2017).

Psd1, for instance, is a plant defensin first isolated from Pisum sativum seeds, which has shown promising effects on C. albicans planktonic cells and biofilm (Gonçalves et al., 2017). Confocal microscopy and AFM analyses revealed that Psd1, at $20 \mu \mathrm{M}$, eradicates C. albicans planktonic cells; however, total inhibition or partial eradication of biofilms were observed at a concentration $10 \mathrm{x}$ greater than the inhibitory value (approximately $200 \mu \mathrm{M}$ ) (Gonçalves et al., 2017). One of the main differences between mammalian and fungal cells is the presence of a cell wall in the latter. Thus, to access the fungal membrane, AFPs have first to interact with cell wall and plasma membrane components, which include sphingolipids, chitin, $\beta$-glucans and mannoproteins. The glycosphingolipid GlcCer, for instance, has been reported as a crucial plasma membrane component for anticandidal activity (planktonic cells and biofilms) of plant defensins (Aerts et al., 2008; Gonçalves et al., 2017). Psd1 acts on C. albicans biofilms by disaggregating the polysaccharide matrix of the cell wall (increasing cell roughness and decreasing its rigidity), followed by membrane permeabilization via interaction with GlcCer (Gonçalves et al., 2017). Once inside the fungal cells, Psd1 accumulation triggers an intracellular mechanism of action by interrupting the cell cycle, leading to apoptosis (Gonçalves et al., 2017). These mechanisms allowed Psd1 to decrease C. albicans planktonic cells' adhesion, leading to the inhibition of biofilm formation, along with the eradication of preformed biofilms (Figures 2A,C).

In addition to Psd1, other plant defensins from Heuchera sanguinea coral bell seeds, named HsAFP1 and HsAFP2, have displayed deleterious antifungal activities against pathogenic fungi (Osborn et al., 1995; Aerts et al., 2011). Interestingly, HsAFP1 has been produced by heterologous expression using the yeast Pichia pastoris, and further denominated rHsAFP1 ( $\mathrm{r}$ - recombinant). $\mathrm{rHsAFP1}$ has shown inhibitory activity against 
A

Inhibition of cell adhesion

\begin{tabular}{|l|}
\hline Psd1 \\
LL-37 \\
Hsn-5 \\
EntV68 \\
\hline
\end{tabular}
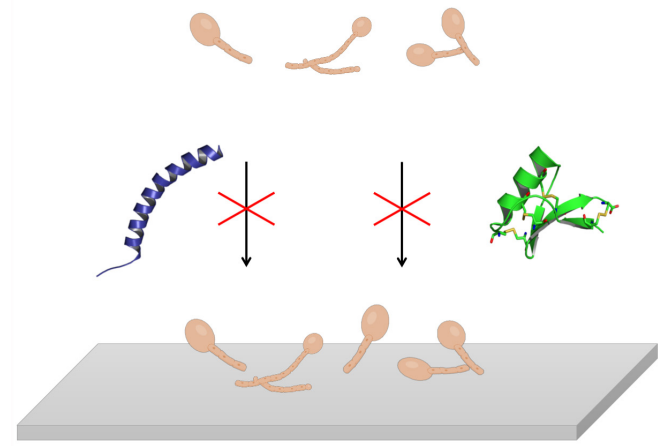

B

Extracellular matrix destabilization

LL-37

BMAP-28

ApoEdpL-W

C

\section{Intracellular mechanims that trigger antibiofilm activities}

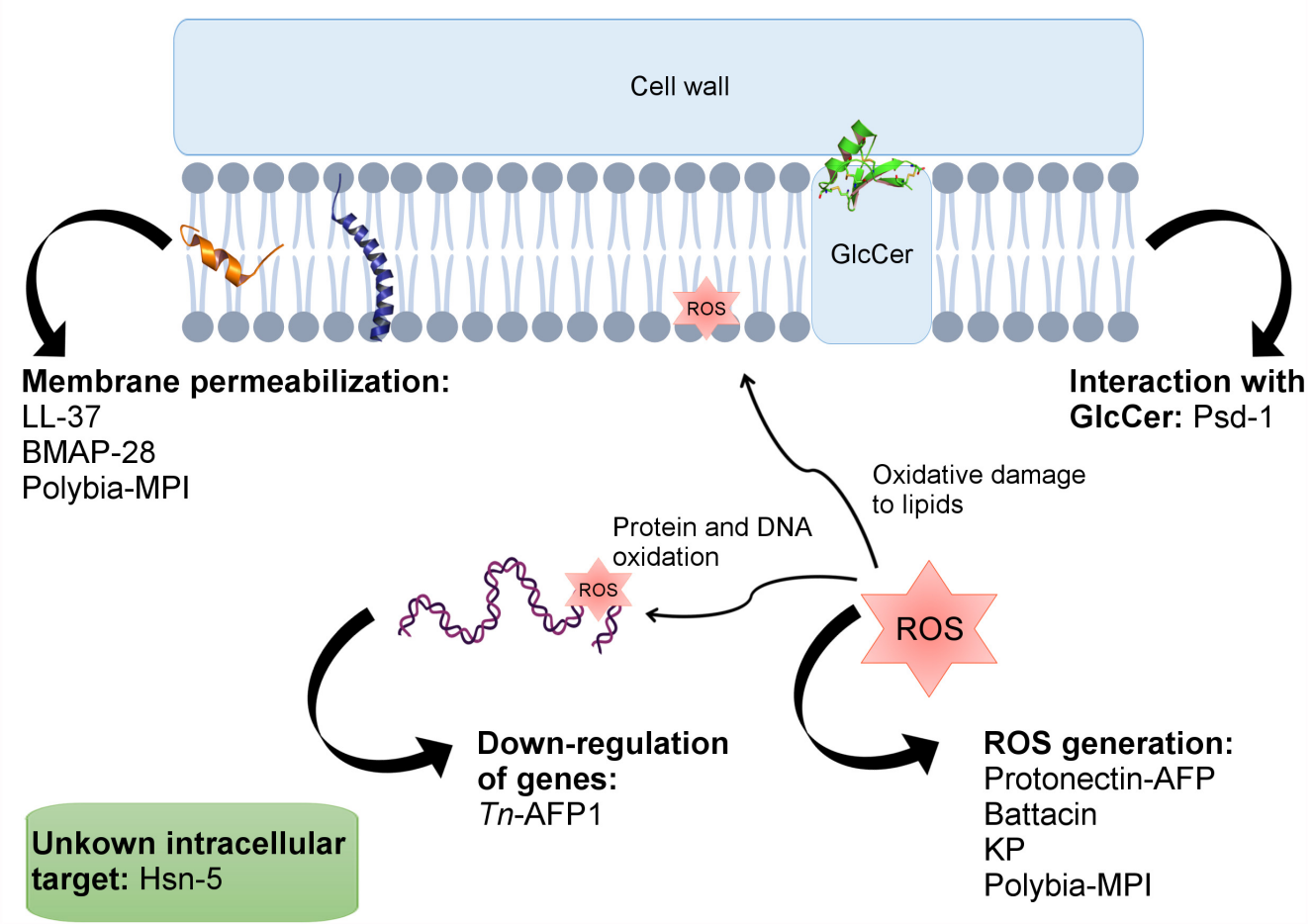

FIGURE 2 | AFPs' mechanisms of action against fungal biofilms. (A) Inhibition of cell adhesion. (B) AFPs' interaction with the extracellular matrix, causing biofilm destabilization. (C) Peptides with intracellular mechanisms that trigger antibiofilm activities. In the boxes are the names of the peptides involved in each mechanism of action. The tridimensional structures present in the figure are: Psd1, in green (PDB: 1JKZ); LL-37 in purple (PDB: 2K60), and BMAP-28 in orange (PDB: 2NDC).

planktonic C. albicans with a value for its MIC 50 (half maximal inhibitory concentration - 50\%) of $18 \mu \mathrm{M}$. In addition, the minimal BIC50 was $11 \mu \mathrm{M}$ (Vriens et al., 2015). In another study, 44 linear peptides derived from HsAFP1 were identified, among which the peptide HsLin06_18 showed antifungal activity (Cools et al., 2017b). This peptide (HsLin06_18) was evaluated against biofilms of $C$. albicans, obtaining a BIC value $>2 \mu \mathrm{M}$. Interestingly, however, when in synergism with Csf this value 
(BIC) is reduced to $0.5 \mu \mathrm{M}$. In another study, a plant defensin isolated from Raphanus sativus antifungal protein 2 (RsAFP2) has also been expressed in P. pastoris. The recombinant peptide, rRsAFP2, has been proved to prevent $C$. albicans biofilm formation $330 \mu \mathrm{M}$ (BIC). In contrary, rRsAFP2 is not capable of eradicating C. albicans biofilm (Vriens et al., 2016).

Plant defensins represent a large class of AFPs that exhibit remarkable stability at extreme $\mathrm{pH}$ and elevated temperature, as well as resistance to protease digestion (Kerenga et al., 2019). Kerenga et al. (2019) carried out a screening for plant defensin sequences in a database with more than 1,200 plant defensins, and identified a Zea mays defensin, named ZmD32, with the highest charge $(+10)$ at $\mathrm{pH} 7$. In this context, the objective of the work was to evaluate whether $\mathrm{ZmD} 32$ with an increased positive charge would retain the activity of the parent peptide at higher salt concentrations. It was observed that $\mathrm{ZmD} 32$ retained activity against a variety of fungal species in media containing high salt concentrations. In addition, $\mathrm{ZmD} 32$ has been shown to be multifunctional, as this peptide acted on fungi and on Gram-negative and Gram-positive bacteria. Moreover, the most prominent activity was observed against $C$. albicans biofilms, as ZmD32 eliminated biofilm viable cells from 20 to $40 \mu \mathrm{M}$ at a physiological sodium concentration $(132.1 \mathrm{mM})$. These findings demonstrate the potential of $\mathrm{ZmD} 32$ as a candidate for antifungal therapies (Kerenga et al., 2019).

\section{$\alpha$-Defensin}

Defensins from vertebrate animals are cationic and amphipathic peptides containing 18-45 amino acid residues. These defensins have been divided into two subfamilies named $\alpha$ and $\beta$-defensins (Parisi et al., 2019). Human peptides have been isolated from neutrophils, playing important roles in processes related to host defense (Szyk et al., 2006; Jarczak et al., 2013). These peptides are cationic (arginine rich), with $3-5 \mathrm{kDa}$ molecular masses, and they are stabilized by disulfide bonds (generally three) (Szyk et al., 2006). Human $\alpha$-defensins have tertiary structure, and these defensins have a short helix structure and $\beta$-sheet stabilized by three disulfide bonds (Szyk et al., 2006).

An example of an $\alpha$-defensin studied for its antifungal actions was human $\alpha$-defensin 6 (HD6). This peptide demonstrated a blocking action of C. albicans adhesion in human intestinal epithelial cells, and treatment with HD6 at concentrations of 10 or $20 \mu \mathrm{M}$ resulted in the prevention of biofilm formation (Chairatana et al., 2017). Some HBDs (e.g., HBD 2, 3, and 4) present antimicrobial properties and, in some cases (Krishnakumari et al., 2009) antifungal activities have been reported (Dhople et al., 2006; Krishnakumari et al., 2009). For instance, the $\alpha$-defensin 6 (HD6) has demonstrated the potential to block C. albicans cells' adhesion on human intestinal epithelial cells. Moreover, the treatment with HD6, at 10 or $20 \mu \mathrm{M}$, resulted in the prevention of biofilm formation (Chairatana et al., 2017).

\section{$\beta$-Defensin}

$\beta$-defensins comprise a large family of AMPs distributed in plants, mammals and insects. These cysteine-rich peptides are cationic and present approximately 45 amino acid residues (Taylor et al., 2008). The tertiary structures of $\beta$-defensins resemble $\alpha$-defensin, the difference being in the position of the disulfide bonds responsible for stabilizing the $\beta$-sheet (Szyk et al., 2006; Shafee et al., 2016). Moreover, $\beta$-defensins have been reported for their multifunctional properties, including antifungal and antifungal biofilm activities (Taylor et al., 2008).

$\beta$-defensins comprise the majority of human defensins described with fungal antibiofilm activity. $\beta$-Human defensins (HBDs) are cationic peptides expressed in inflamed dental pulp (Paris et al., 2009). Similarly, different synthetic defensin-like peptides, including $\alpha$-defensin-3, $\beta$-defensin-1, $\beta$-defensin- 3 and PG-1, have demonstrated potent antifungal activity against C. neoformans biofilms. These peptides were effective against planktonic cells and mature biofilms, whereas PG-1, at $8 \mu \mathrm{M}$, reduced the survival percentage of cryptococcal biofilms by approximately $50 \%$. $\beta$-defensin- 1 , at the same concentration, reduced biofilm survival by $60 \%$, whereas $\alpha$-defensin- 3 and $\beta$-defensin-3 reduced biofilm survival by approximately $30 \%$ (Martinez and Casadevall, 2006). Interestingly, a 15-amino acid residue peptide derived from the $\mathrm{C}$-terminus region of the human defensin 3 (HBD3-C15) has also revealed antifungal activity in a dose-dependent manner $(28.3-169.8 \mu \mathrm{M})$ against $C$. albicans biofilm when evaluated on dentin disks (Lim et al., 2016).

The AFPs here cited are mainly active against $C$. albicans and C. neoformans. Plant defensins are stable AFPs with antifungal action and are capable of inhibiting biofilm formation, as well as eradicating preformed biofilms. In addition, these AFPs have also been proved to act in synergism with conventional antifungal agents, including HsLin06_18 peptide in combination with Csf, which acts on C. albicans biofilm formation (Vriens et al., 2016). Although these defensins have been proved to prevent fungal cell adhesion and, consequently, biofilm formation, more detailed studies regarding their antifungal biofilm activities are still scarce (van der Weerden et al., 2010). Therefore, further investigations with $\alpha$-defensins are needed to demonstrate the real potential and mechanisms of action for this class of AFP. The same could be expected for $\beta$-defensins, which are active against fungal planktonic cells and biofilms, although the mechanisms by which they operate on different cellular organizations have not been yet elucidated. Thus, the findings here summarized, especially for plant defensins, represent an attractive field for further structurefunction studies, aiming at correlating some of the already available tridimensional structures with AFPs' mechanisms of action and, finally, identifying determinants for the generation of optimized AFPs that specifically target fungal biofilms. The AFPs described in the Defensin-like peptides section, their respective antibiofilm activities, and their proposed mechanisms of action are summarized in Table 1.

\section{Cathelicidins}

Peptides from the cathelicidin family have been isolated from different species of mammals and exhibit broad-spectrum activities against fungi (Zanetti, 2004). Cathelicidins are characterized as cationic peptides, consisting of 12-80 amino acids that adopt an $\alpha$-helix or $\beta$-sheet as secondary structures, most of which have 23-37 amino acid residues distributed in amphipathic helices, including LL-37 and BMAP-28 (Figure 1) (Zanetti et al., 1995; Gennaro and Zanetti, 2000). 
TABLE 1 | Defensin-like peptides against pathogenic fungi and biofilms and their proposed mechanisms of action.

\begin{tabular}{|c|c|c|c|c|c|c|}
\hline Peptide & Source & Activity & Concentration $(\mu \mathrm{M})$ & Pathogen & $\begin{array}{l}\text { Mechanism of } \\
\text { actions }\end{array}$ & References \\
\hline Psd1 & $P$. sativum seeds & $\begin{array}{l}\text { Biofilm } \\
\text { inhibition }\end{array}$ & $\sim 200$ & C. albicans & $\begin{array}{l}\text { Cell cycle interruption, } \\
\text { leading to apoptosis }\end{array}$ & Gonçalves et al., 2017 \\
\hline rHsAFP1 & $\begin{array}{l}\text { H. sanguinea coral bell } \\
\text { seeds ( } r \text { - recombinant) }\end{array}$ & $\begin{array}{l}\text { Biofilm } \\
\text { inhibition }\end{array}$ & BIC50* 11 & C. albicans & Not determined & Vriens et al., 2015 \\
\hline rRsAFP2 & $\begin{array}{l}\text { H. sanguinea coral bell } \\
\text { seeds ( } r \text { - recombinant) }\end{array}$ & $\begin{array}{l}\text { Biofilm } \\
\text { inhibition }\end{array}$ & $\mathrm{BIC}^{*} 330$ & C. albicans & Not determined & Vriens et al., 2016 \\
\hline HsLin06_18 & Derived from rHsAFP1 & $\begin{array}{l}\text { Biofilm } \\
\text { inhibition }\end{array}$ & $\begin{array}{l}\mathrm{BIC}^{*}>2 ; \text { and } 0.5 \\
\text { synergism with Csf }\end{array}$ & C. albicans & Not determined & Cools et al., 2017b \\
\hline ZmD32 & Z. mays & $\begin{array}{l}\text { Biofilm } \\
\text { inhibition }\end{array}$ & $20-40$ & C. albicans & Not determined & Kerenga et al., 2019 \\
\hline HD6 & Human defensin & $\begin{array}{l}\text { Biofilm } \\
\text { inhibition }\end{array}$ & $10-20$ & C. albicans & Not determined & Chairatana et al., 2017 \\
\hline $\begin{array}{l}\beta \text {-defensin } 1, \\
\beta \text {-defensin } 3 \text {, } \\
\text { PG-1 }\end{array}$ & Human defensins & $\begin{array}{l}\text { Biofilm } \\
\text { inhibition }\end{array}$ & 8 & C. neoformans & Not determined & Martinez and Casadevall, 2006 \\
\hline HBD3-C15 & Human defensin & $\begin{array}{l}\text { Biofilm } \\
\text { inhibition }\end{array}$ & $\begin{array}{c}\text { Dose-dependent } \\
(28,3-169,8)\end{array}$ & C. albicans & Not determined & Lim et al., 2016 \\
\hline
\end{tabular}

* References values for each experiment, which can be: BIC, biofilm inhibition concentration; BIC50, concentration required to reduce biofilm formation by $50 \%$.

The activities of LL-37 and BMAP-28 have been investigated against Candida spp. strains (clinical isolates of vaginal infections) in terms of planktonic cells' growth inhibition and interference in fungal cell adhesion on polystyrene and silicone surfaces (biofilm formation) (Scarsini et al., 2015). LL-37, at $64 \mu \mathrm{M}$, was capable of inhibiting C. albicans cell adhesion on the tested surfaces (Scarsini et al., 2015). In that same work, BMAP-28, at $16 \mu \mathrm{M}$, was capable of inhibiting 70-90\% of $C$. albicans and Candida krusei mature biofilms. BMAP28 also reduced the number of $C$. albicans adherent cells on silicone surfaces, indicating its usage as an antifungal agent in coaching strategies (medical devices) (Scarsini et al., 2015). In addition to LL-37 and BMAP-18, a peptide derived from a cathelicidin-related AMP (CRAMP), named AS10, inhibited C. albicans biofilm formation at $0.22 \mu \mathrm{M}$ (De Brucker et al., 2014). Furthermore, in synergism with Csf or amphotericin B, AS10 also acted on C. albicans mature biofilms (De Brucker et al., 2014). In that same work, another peptide, named P318, demonstrated even higher antifungal activity $(0.15 \mu \mathrm{M})$ against C. albicans biofilms, without affecting planktonic cells' survival (De Brucker et al., 2014).

The human cathelicidin LL-37 inhibits C. albicans adhesion and aggregation (2.2 and $4.5 \mu \mathrm{M})$ on biotic and abiotic surfaces by interacting with chitin, glucan and, especially, mannan present in the cell wall of this pathogen (Figure 2C) (Tsai et al., 2011). This ability has also been emphasized as a crucial mechanism by which LL-37 inhibits $C$. albicans biofilm formation on both medical devices and biological tissues in the course of $C$. albicans infections (Tsai et al., 2011). Moreover, to evaluate whether LL37 interaction with mannan is selective for C. albicans or not, this AFP was also tested regarding its ability to interact with Saccharomyces cerevisiae mannan. As a result, LL-37 was not recovered by mannan from $S$. cerevisiae and, therefore, this AFP had no influence on cell aggregation and cell adhesion in this fungal strain (Figure 2A) (Tsai et al., 2011). It is known that the main difference between $C$. albicans and $S$. cerevisiae mannan is the presence of $\beta-1,2$ linkages in the first one (Shibata et al., 1985). This exclusive feature in C. albicans mannan was also proposed in that work (Tsai et al., 2011) as an important factor for LL-37 cell adhesion inhibitory potential, highlighting the application of this AFP in antibiofilm strategies.

Cathelicidins are peptides that are well described in the literature for their broad-spectrum activities and relatively stable structures. Cathelecidins have potential for the development of drugs that could be used on medical devices to combat fungal biofilms. Furthermore, the studies cited here demonstrate that this class can act synergistically with the conventional antifungal agents, rendering these peptides a promising starting point for future combinatorial therapies. The AFPs described in this section, their respective antibiofilm activities, and their proposed mechanisms of action are summarized in Table 2.

\section{Histatins}

Human salivary histatins are a group of small histidine-rich proteins constituted from 7 to 38 amino acids first isolated from human parotid saliva (Oppenheim et al., 1988). In general, histatins are a multifunctional group of proteins with antimicrobial properties that vary from broad-spectrum to moderate activities (Troxler et al., 1990). Moreover, histatins have been reported for their effective antifungal activity (Troxler et al., 1990; Tsai and Bobek, 1998). Histatins are divided into three major peptides, named histatin-1, histantin-3 and histatin5 , varying from 24 to 38 amino acid residues in length. They are polar and hydrophilic peptides presenting an $\alpha$-helical structural conformation in organic solutions (Oppenheim et al., 1988). Therefore, histatin peptides have promising antifungal activities and their membrane affinity has been studied in the context of fungal infections (Brewer et al., 1998).

It is known that diverse pathogenic fungi can form biofilms on polymer surfaces, oral prostheses and medical devices. In that 
context, the activity of the Hst-5 peptide has been evaluated against C. albicans biofilms (CAI-4), demonstrating that this peptide, at $50 \mu \mathrm{M}$, inhibited biofilm formation on acrylic dentures in vitro (Pusateri et al., 2009). In another study, the potential of Hsn-5 was evaluated against planktonic cells and biofilms of C. albicans and C. glabrata growth on poly (methyl methacrylate) disks, simulating oral prostheses (Konopka et al., 2010). Hsn-5 was capable of inhibiting planktonic C. albicans strains with MICs ranging from 2.6 to $4.8 \mu \mathrm{M}$. In contrast, planktonic C. glabrata cells were insensitive to Hsn-5. Moreover, this peptide also caused a reduction in the biofilm metabolic activity (RMA) with concentrations ranging from 1.7 to $6.9 \mu \mathrm{M}$ and from 31.2 and $62.5 \mu \mathrm{M}$ against C. albicans and C. glabrata biofilms, respectively (Konopka et al., 2010).

Diverse studies have been carried out over recent decades aiming to understand the mechanism of histatin fungicidal activity. According to the literature, Hsn-5 acts by a multistep mechanism. First, the peptide is internalized by endocytosis, followed by its binding to the cell wall and further translocation across the membrane to act on intracellular targets (Figure 2C) (Sun et al., 2008). Hsn-5 can enter C. albicans by means of an energy-dependent or -independent mechanism (Moffa et al., 2015). Although we do not have complete evidence on the mechanisms of action of Hsn-5, studies have shown that the same peptide often has different mechanisms against planktonic cells and biofilms (Sun et al., 2008).

Some authors report that histidine-rich peptides, including the histatins cited in this section, are highly selective antifungals and have little toxicity toward mammalian cells. According to data here summarized, histatins demonstrate promising antifungal activities, making these AFPs potential candidates for biofilm treatment, especially oral fungal infections. However, although they have elucidated mechanisms of action against planktonic cells, histatin studies still lack deeper information on fungal antibiofilm properties and mechanisms of action, making this class a potential subject for further studies aimed at combating fungal biofilms, determining their tridimensional structures, as well as unraveling their mechanisms of action. The AFPs described in this section, their respective antibiofilm activities, and their proposed mechanisms of action are summarized in Table 3.

\section{Miscellaneous AFPs That Act on Fungal Biofilms}

In addition to the above-mentioned classes of AFPs with antibiofilm potential, studies have also described additional AFPs from different sources that target fungal cell adhesion, thus inhibiting biofilm formation, as well as preformed biofilms. Ergosterol is the main sterol that constitutes fungal membranes. Moreover, studies have shown that the overexpression of genes involved in the biosynthesis of ergosterol (e.g., ERG11, ERG16 and ERG25) may be crucial for Candida species biofilm formation (Garcia-Sanchez et al., 2004). For instance, the peptide Tn-AFP1, which is derived from Trapa natans, demonstrated antifungal potential by inhibiting planktonic cells of $C$. tropicalis at $26 \mu \mathrm{M}$. Moreover, it has been reported that Tn-AFP1 is capable of inhibiting fungal biofilm formation in a dose-dependent manner, as well as eradicating preformed biofilms (Mandal et al., 2011). In addition, when evaluating the levels of expression of two

TABLE 2 | Cathelicidin peptides against pathogenic fungi and biofilms and their proposed mechanisms of action.

\begin{tabular}{|c|c|c|c|c|c|c|}
\hline Peptide & Source & Activity & $\begin{array}{c}\text { Concentration } \\
(\mu \mathrm{M})\end{array}$ & Pathogen & $\begin{array}{l}\text { Mechanism of } \\
\text { actions }\end{array}$ & References \\
\hline LL-37 & Human cathelicidin & Inhibited cell adhesion & 64 & $\begin{array}{l}\text { C. krusei } \\
\text { C. albicans }\end{array}$ & $\begin{array}{l}\text { Membrane } \\
\text { permeabilization }\end{array}$ & Scarsini et al., 2015 \\
\hline BMAP-28 & Bovine cathelicidin & $\begin{array}{l}\text { Biofilm inhibition - } \\
\text { Biofilm eradication }\end{array}$ & 16 & $\begin{array}{l}\text { C. albicans, } \\
\text { C. glabrata, } \\
\text { C. krusei }\end{array}$ & $\begin{array}{l}\text { Membrane } \\
\text { permeabilization }\end{array}$ & Scarsini et al., 2015 \\
\hline AS10 P318c & Derived from BMAP-18 & Biofilm inhibition & $\begin{array}{l}0.22 \\
0.15\end{array}$ & C. albicans & Not determined & De Brucker et al., 2014 \\
\hline LL-37 & Human cathelicidin & Biofilm inhibition & 2.2 and 4.5 & C. albicans & $\begin{array}{l}\text { Adhesion and } \\
\text { aggregation inhibition } \\
\text { on biotic and abiotic } \\
\text { surfaces }\end{array}$ & Tsai et al., 2011 \\
\hline
\end{tabular}

TABLE 3 | Histatin peptides against pathogenic fungi and biofilms and their proposed mechanisms of action.

\begin{tabular}{|c|c|c|c|c|c|c|}
\hline Peptide & Source & Activity & $\begin{array}{l}\text { Concentration } \\
(\mu \mathrm{M})\end{array}$ & Pathogen & Mechanism of actions & References \\
\hline Hst-5 & $\begin{array}{l}\text { Human salivary } \\
\text { histatins }\end{array}$ & $\begin{array}{l}\text { Biofilm } \\
\text { inhibition }\end{array}$ & 50 & C. albicans & Not determined & Pusateri et al., 2009 \\
\hline Hsn-5 & $\begin{array}{l}\text { Human salivary } \\
\text { histatins }\end{array}$ & $\begin{array}{l}\text { Biofilm } \\
\text { inhibition }\end{array}$ & $\begin{array}{c}1.7-6.9 \\
4.8 \\
31.2-62.5\end{array}$ & $\begin{array}{l}\text { C. albicans } \\
\text { C. glabrata }\end{array}$ & $\begin{array}{l}\text { Peptide is internalized by } \\
\text { endocytosis, then it binds to } \\
\text { the cell wall and translocates } \\
\text { into the cell to act on } \\
\text { intracellular targets }\end{array}$ & $\begin{array}{l}\text { Sun et al., 2008; } \\
\text { Konopka et al., } 2010\end{array}$ \\
\hline
\end{tabular}


genes related to biofilm formation, including ERG11 (ergosterol biosynthesis) and $M D 1 R$ (ATP-binding cassettes pump) it was observed that planktonic cells treated with Tn-AFP1 presented the down-regulation of these genes and, therefore, could not establish biofilms (Figure 2C) (Mandal et al., 2011). Moreover, this AFP also induced morphological cell changes, along with fungicidal effects on biofilm-constituting cells.

In addition, a decapeptide isolated from Arabidopsis thaliana, called OSIP108, was evaluated regarding its antifungal and antibiofilm properties on C. albicans (De Coninck et al., 2013). As a result, the authors observed that OSIP108, from 2 to $>200 \mu \mathrm{M}$, did not display antifungal activity against $C$. albicans planktonic cells, whereas OSIP108, from 6.25 to $100 \mu \mathrm{M}$, reduced C. albicans biofilm formation when administrated during the cell adhesion stage. These findings indicate that, despite using the same AFP, its antifungal and antibiofilm modes of action are most likely to be independent, as AFPs that are promising against planktonic cells may present ineffective antibiofilm properties and vice versa.

As described above, human-derived peptides have also been pinpointed as promising antifungal agents. A tryptophanrich peptide derived from the human ApoE apolipoprotein (ApoEdpL-W), for instance, has shown antifungal activity against pathogenic yeasts of the Candida species, except for C. glabrata (Rossignol et al., 2011). ApoEdpL-W was active against planktonic cells and biofilms at early stages, but less active against mature biofilms $(10$ to $80 \mu \mathrm{M})$. In addition, ApoEdpL-W partially prevented biofilm formation on medical devices (Rossignol et al., 2011). Fungal cells in biofilms are embedded in an extracellular matrix composed of exopolymeric compounds, including $\beta-1,3$ glucan. Taking that into account, Rodrigues et al. (2018) evaluated the susceptibility of C. glabrata biofilms to echinocandins (cyclic lipo-hexapeptides), including Csf and micafugin (Mcf), also shedding some light on how these two AFPs interfere in $\beta-1,3$ glucan concentration in the matrix of C. glabrata biofilms. The authors observed that C. glabrata preformed biofilms treated with Csf and Mcf presented adjustments in the matrix composition due to a decrease in $\beta-1,3$ glucan concentration (Rodrigues et al., 2018). These findings were further correlated with the antibiofilm potential of these two AFPs, partially elucidating their antibiofilm mechanism (Rodrigues et al., 2018). A similar hypothesis has also been proposed for the higher antibiofilm activity of the tryptophan-rich AFP, ApoEdpL-W, against early-stage C. albicans biofilms when compared to mature biofilms (Rossignol et al., 2011). This finding can be partially explained by the affinity of ApoEdpL-W for extracellular matrix $\beta$-glucans in mature biofilms (e.g., $\beta-1,3$ glucan), which is known to trap antifungal agents and, consequently, confer biofilm tolerance (Figure 2B) (Rossignol et al., 2011).

Insect peptides are also known for their broad-spectrum of biological activities. Polybia-MPI, for instance, was originally isolated from the venom of the social wasp Polybia paulista and presented potent antibacterial activity (Souza et al., 2005). To better understand peptide biological potential, Polybia-MPI was evaluated for its inhibitory, fungicidal and antibiofilm activities against Candida spp. (Wang et al., 2014). PolybiaMPI revealed MIC and MFC values of 16 and $32 \mu \mathrm{M}$ against
C. albicans, respectively, whereas C. glabrata was inhibited (MIC) and killed (MFC) by Polybia-MPI at 8 and $32 \mu \mathrm{M}$, respectively. In addition, Polybia-MPI inhibited C. glabrata biofilm formation on polystyrene surface from $2 \times$ MIC to $8 \times$ MIC, resulting in a drastic decrease of biofilm biomass (Wang et al., 2014).

Another example of an AFP isolated from wasp toxin is the protonectin peptide, which was originally isolated from Agelaia pallipes pallipes (Mendes et al., 2004). Protonectin has been evaluated against C. glabrata, C. albicans, C. parapsilosis, C. tropicalis and C. krusei, revealing MICs from 8 to $128 \mu \mathrm{M}$. Protonectin was also found to disrupt fungal membrane integrity and induce the production of cellular reactive oxygen species (ROS), inhibiting the formation of C. glabrata biofilms (Wang et al., 2015). Wang et al. (2015), for instance, observed that a protonectin AFP, derived from the venom of a social wasp, has potent antifungal and fungicidal activities. Moreover, this AFP not only inhibited biofilm formation, but also killed adherent biofilm cells. All these activities were further correlated with membrane-associated mechanisms, along with the generation of ROS (Figure 2C) (Wang et al., 2015). In fungi, ROS are generated as metabolic products from an endogenous or exogenous source and include hydrogen peroxide and hydroxyl radicals, which act as signaling molecules for gene regulation (Scandalios, 2002; Cho and Lee, 2011). Inside fungal cells, ROS generation is balanced by the production of antioxidants. However, when this balance is compromised (for instance, by the presence of AFPs) ROS accumulation may lead to oxidative damage to lipids, proteins and DNA, resulting in cell death (Scandalios, 2002; Cho and Lee, 2011). In antifungal therapies focusing on AFPs, antifungal properties toward fungal biofilms have been reported and, in some cases, associated with ROS generation. Similar findings were reported for linear battacin peptides against $C$. albicans mature biofilms (Figure 2C) (De Zoysa et al., 2018).

Peptides derived from insect venom have also been submitted to sequence optimization strategies aiming at improved antifungal properties. Lasioglossin-III (LL-III) and halitin (HAL2), for instance, represent two peptides derived from bee venom (Čeřovský et al., 2009) that were used as template molecules for the generation of synthetic analogs, named LL-III/43 and peptide VIII, respectively. These analogs were evaluated for their antifungal and antibiofilm activities against Candida spp. The lowest MIC $(0.8 \mu \mathrm{M})$ value was observed for LL-III/43 against C. tropicalis. Moreover, both analogs inhibited Candida spp. biofilm formation, with concentrations ranging from 0.9 to $58.6 \mu \mathrm{M}$. Biofilm eradication for almost all Candida species tested ranged from 12.8 to $200 \mu \mathrm{M}$ (Kočendová et al., 2019).

Bacteriocins are examples of peptides produced by various bacterial species with antifungal action (Sang and Blecha, 2008). $\mathrm{EntV}$ is a bacteriocin encoded by the entV locus (ef1097) from Enterococcus faecalis (Graham et al., 2017), originally studied for its antibacterial activity against Gram-positive strains (Swe et al., 2007). Graham et al. (2017) have reported a synthetic bacteriocin version, named $\mathrm{EntV}^{68}$, which is constituted of 68 amino acid residues with one disulfide bond involved in structure cyclization. $\mathrm{EntV}^{68}$ has been shown to be effective for reducing virulence of C. albicans strains and biofilm formation by inhibiting hyphae formation $(\mathrm{BIC50}=0.0003 \mu \mathrm{M})($ Figure 2A). Furthermore, this 
peptide potentially blocks biofilm development in solid substrates under multi-media conditions and has been proved to disturb preformed biofilms that are resistant to current antifungal agents (Graham et al., 2017). In addition, that work also evaluates whether $\mathrm{EntV}^{68}$ protected phagocytes from C. albicans-induced damage or not (Graham et al., 2017). The murine RAW 264.7 macrophages were incubated with $C$. albicans cells in the presence and absence of $\mathrm{EntV}^{68}$, at $100 \mathrm{nM}(0.0001 \mu \mathrm{M})$. Under the peptide presence, the authors observed a decrease in the release of lactate dehydrogenase $(\mathrm{LDH})$, an enzyme present in the macrophage membrane. Moreover, the analysis showed fewer surviving fungal cells, indicating that $\mathrm{EntV}^{68}$ reduces fungusinduced cytotoxicity and may potentiate macrophage antifungal activity (Graham et al., 2017). Therefore, EntV ${ }^{68}$ has clear pharmacological potential, as this peptide is capable of inhibiting biofilm formation and also disturbing preformed biofilms, without causing cytotoxicity in macrophages. In addition, two in vivo experiments were performed, which will be described later in the section "AFPs used to counter fungal infections in animal models."

In addition to insects, other arthropods and also bacteria can be a rich source of bioactive peptide screening. Lichosin1, which is derived from Lycosa singoriensi spider venom (Tan et al., 2018), showed antifungal activity against clinical isolates of fluconazole-resistant C. albicans, with MIC values from 0.31 and $0.67 \mu \mathrm{M}$. When this peptide was evaluated against C. albicans biofilm, it was capable of inhibiting biofilm formation from 2.75 to $70.73 \mu \mathrm{M}$. However, higher concentrations ranging from 136.25 to $694.47 \mu \mathrm{M}$ were required for antibiofilm activities against mature biofilms (Tan et al., 2018). In addition, Lycosin-1 acts against C. tropicalis through several types of morphological damage, leading to decreased biofilm filamentation, along with an increased number of gaps between cell clusters within the biofilms (Tan et al., 2018).

Another study evaluated optimized synthetic peptides called kaxins, capable of inhibiting fluconazole-susceptible and resistant C. albicans, C. tropicalis and C. glabrata strains (128 to $512 \mu \mathrm{M}$ ) (Burrows et al., 2006). In that work, it was observed that a kaxin peptide, named dF21-10K, completely eradicated C. albicans and C. tropicalis preformed biofilms in a concentration 10-fold higher than the MIC against these strains (61.5 to $246.1 \mu \mathrm{M}$ ) (Burrows et al., 2006).

Also in the field of synthetic peptides, a decapeptide known as killer peptide (KP) was described (Paulone et al., 2017). This peptide was tested against fluconazole-resistant and -susceptible C. albicans biofilms at different development stages (cell adhesion, development of hyphae and extracellular matrix production). KP exerted fungicidal activity against all planktonic strains investigated, with MFC from 0.31 to $0.67 \mu \mathrm{M}$. The inhibitory effects of $\mathrm{KP}$ in $C$. albicans biofilm's early stages showed that $124.2 \mu \mathrm{M}, \mathrm{KP}$ impaired the biofilms, reducing the total biomass by more than $45 \%$ in four strains. Furthermore, the inhibitory effects of KP on mature (2-day old) biofilms of $C$. albicans showed that, at 124.2 $\mu \mathrm{M}, \mathrm{KP}$ significantly impaired the total biomass of mature biofilms. In addition, KP administration led to an increased oxidative stress response in C. albicans, showing that this peptide has inhibitory effects on C. albicans biofilm regardless of whether this pathogen is resistant or susceptible to fluconazole (Paulone et al., 2017). AFPs can present multiple mechanisms against fungal biofilms depending on their stage, including early and mature biofilms. Recently, it was reported that a synthetic killer decapeptide (KP) was capable of inhibiting fluconazole-susceptible and -resistant C. albicans biofilm formation, also significantly affecting the viability of preformed biofilms (Paulone et al., 2017). In that work, KP induced ROS production in mature biofilms and also decreased the viability of biofilm-constituting fungal cells through membrane permeabilization (Paulone et al., 2017). Moreover, the transcriptional profile of C. albicans biofilms in early and mature stages treated with KP indicates that this AFP reduced the expression of biofilm-associated genes, including matrix-related genes and hyphal-specific genes (Figure 2C) (Rodrigues et al., 2018).

Battacin, a cyclic lipopeptide isolated from Paenibacillus tianmuensis, has shown promising antibacterial activities (Qian et al., 2012). De Zoysa et al. (2015) developed 16 battacin linear analogs, observing an improvement in their activity against bacterial biofilms. Based on that, these analogs were also submitted to fungal antibiofilm assays. As a result, the authors identified the three most effective analogs (3, 12, and 13), which were capable of inhibiting planktonic cells of $C$. albicans at 50, 12.5, and $6.25 \mu \mathrm{M}$, respectively. Since the lowest inhibitory concentration was observed for analog 13, it was evaluated against C. albicans biofilms. Analog 13 showed BIC50 values of $6.25 \mu \mathrm{M}$ and was able to eradicate pre-formed biofilms $62.5 \mu \mathrm{M}$ (10 times its MIC) (De Zoysa et al., 2018). The AFPs described in this section, their respective antibiofilm activities, and their proposed mechanisms of action are summarized in Table 4.

\section{AFPs USED TO COUNTER FUNGAL INFECTIONS IN ANIMAL MODELS}

In general, antifungal and antibiofilm peptides are tested in murine models, although different models have been developed in primates, rabbits, guinea pigs, birds, and canines (Hohl, 2014; Dijck et al., 2018). Animal models are an effective method by which to evaluate the progression of fungal pathogenesis and host immune responses and to investigate the antifungal properties of drug candidates (Capilla et al., 2007; Hohl, 2014; Dijck et al., 2018). These models allow the control of different biological variables, mimicking human diseases and monitoring disease progress (Capilla et al., 2007; Dijck et al., 2018). Recently, studies have used non-vertebrate models to optimize the screening of candidate drugs and evaluate fungal virulence. Non-vertebrate and other animal models are described in Table 5. According to Segal and Frenkel (2018), animal models are classified based on methods of therapeutic evaluation, including superficial (skin, nails), mucosal (oral, vaginal), gastrointestinal and lung or systemic infections (intravenous, intraperitoneal) 
TABLE 4 | Unusual AFP classes of peptides against pathogenic fungi and biofilms and their proposed mechanisms of action.

\begin{tabular}{|c|c|c|c|c|c|c|}
\hline Peptide & Source & Activity & Concentration $(\mu \mathrm{M})$ & Pathogen & $\begin{array}{l}\text { Mechanism of } \\
\text { actions }\end{array}$ & References \\
\hline Tn-AFP1 & T. natans & $\begin{array}{l}\text { Antifungal- Biofilm } \\
\text { inhibition - Biofilm } \\
\text { eradication }\end{array}$ & $\begin{array}{l}26 \text { (inhibition) } 52 \\
\text { (eradication) }\end{array}$ & C. tropicalis & $\begin{array}{l}\text { Down-regulation of } \\
\text { genes (ERG11 and } \\
\text { MD1R) and, } \\
\text { therefore, cannot } \\
\text { establish biofilms }\end{array}$ & $\begin{array}{l}\text { Mandal et al., } \\
2011\end{array}$ \\
\hline $\mathrm{dF} 21-10 \mathrm{~K}$ & Synthetic peptide & Biofilm eradication & $61.5-246.1$ & $\begin{array}{l}\text { C. albicans } \\
\text { C. tropicalis }\end{array}$ & Not determined & $\begin{array}{l}\text { Burrows et al., } \\
2006\end{array}$ \\
\hline OSIP108 & A. thaliana & Biofilm inhibition & $6.25-100$ & C. albicans & Not determined & $\begin{array}{l}\text { Delattin et al., } \\
2014\end{array}$ \\
\hline ApoEdpl-W & $\begin{array}{l}\text { Human ApoE } \\
\text { apolipoprotein }\end{array}$ & Biofilm inhibition & $10-80$ & $\begin{array}{l}\text { Candida spp., except } \\
\text { for C. glabrata }\end{array}$ & $\begin{array}{l}\text { Affinity for } \\
\text { extracellular matrix } \\
\beta \text {-glucans in mature } \\
\text { biofilms, conferring } \\
\text { biofilm tolerance }\end{array}$ & $\begin{array}{l}\text { Rossignol et al., } \\
2011\end{array}$ \\
\hline Polybia-MPI & P. paulista & Biofilm inhibition & $16-328-32$ & $\begin{array}{l}\text { C. albicans, } \\
\text { C. glabrata }\end{array}$ & Generation of ROS & $\begin{array}{l}\text { Wang et al., } \\
2014\end{array}$ \\
\hline $\begin{array}{l}\text { LL-III/43 } \\
\text { Peptide VIII }\end{array}$ & Bee venom & $\begin{array}{l}\text { Biofilm inhibition - } \\
\text { Biofilm eradication }\end{array}$ & $\begin{array}{c}0.9-58.6 \text { (inhibition) } \\
12.8 \text { - } 200 \text { (eradication) }\end{array}$ & $\begin{array}{l}\text { C. tropicalis Candida } \\
\text { spp. }\end{array}$ & Not determined & $\begin{array}{l}\text { Kočendová } \\
\text { et al., } 2019\end{array}$ \\
\hline $\mathrm{KP}$ & Synthetic peptide & $\begin{array}{l}\text { Biofilm inhibition Biofilm } \\
\text { eradication }\end{array}$ & $0.31-0.67124 .2$ & C. albicans & $\begin{array}{l}\text { ROS generation in } \\
\text { mature biofilms and } \\
\text { membrane } \\
\text { permeabilization }\end{array}$ & $\begin{array}{l}\text { Paulone et al., } \\
2017\end{array}$ \\
\hline $\begin{array}{l}\text { Protonectin } \\
\text { AFP }\end{array}$ & A pallipes pallipes & $\begin{array}{l}\text { Biofilm inhibition - } \\
\text { Biofilm eradication }\end{array}$ & - & C. albicans & ROS generation & $\begin{array}{l}\text { Wang et al., } \\
2015\end{array}$ \\
\hline Battacin & P. tianmuensis & $\begin{array}{l}\text { Biofilm inhibition - } \\
\text { Biofilm eradication }\end{array}$ & $\begin{array}{c}\text { BIC50* } 6.25 \text { (inhibition) } \\
62.5 \text { (eradication) }\end{array}$ & C. albicans & ROS generation & $\begin{array}{l}\text { De Zoysa et al., } \\
2018\end{array}$ \\
\hline Lichosin-1 & L. singoriensi & $\begin{array}{l}\text { Biofilm inhibition - } \\
\text { Biofilm eradication }\end{array}$ & $2.75-70.73$ & C. albicans & Not determined & Tan et al., 2018 \\
\hline EntV68 & $\begin{array}{l}\text { bacteriocin of } \\
\text { E. faecalis }\end{array}$ & $\begin{array}{l}\text { Biofilm inhibition - } \\
\text { blocking biofilm } \\
\text { development }\end{array}$ & $\begin{array}{c}\mathrm{BIC50*} 0.0003 \\
0.0001\end{array}$ & $\begin{array}{l}\text { C. albicans (virulence } \\
\text { and biofilm } \\
\text { development) } \\
\text { C. albicans, C. } \\
\text { tropicalis, C. } \\
\text { parapsilosis C. glabrata } \\
\text { (inhibition of formed } \\
\text { biofilms) }\end{array}$ & $\begin{array}{l}\text { Reduces virulence } \\
\text { of } C \text {. albicans } \\
\text { strains and biofilm } \\
\text { formation by } \\
\text { inhibiting hyphae } \\
\text { formation blocking } \\
\text { biofilm } \\
\text { development in } \\
\text { solid substrates } \\
\text { under multi-media } \\
\text { conditions }\end{array}$ & $\begin{array}{l}\text { Graham et al., } \\
2017\end{array}$ \\
\hline
\end{tabular}

*Reference values for each experiment, which can be: BIC50, concentration required to reduce biofilm formation by 50\%.

(Capilla et al., 2007; Hohl, 2014; Dijck et al., 2018). In addition, antifungal drugs have limited efficiency against invasive fungal infections, directly impacting increasing mortality rates (Hohl, 2014).

In this context, studies with animal models demonstrate a reliable strategy for evaluating the effectiveness of AFPs on biofilm-associated fungal infections, thus helping researchers to elucidate the therapeutic application of these antifungal agents in the clinic. Therefore, here we described different AFPs with activity against fungal biofilm in distinct animal models. Cools et al. (2017b) tested HsLin06_18 (derived from the plant defensin HsAFP1) in association with Csf. This combination was tested in immunosuppressed female SpragueDawley rats. C. albicans biofilms were formed inside catheters $\left(5 \times 10^{4}\right.$ cells. $\left.\mathrm{mL}^{-1}\right)$, which were further implanted into the back area of the rats. The antibiofilm treatment aiming to inhibit biofilm formation was initiated immediately after the implant. The combination Csf + HsLin06_18 and the control group were administered intravenously or subcutaneously once daily for 7 days. It was demonstrated that the combination Csf + HsLin06_18 reduced C. albicans biofilm formation in vivo compared to the untreated control, besides not presenting cytotoxicity in healthy cells. Similar effects have been observed for an insect defensin, named drosomycin, against Botrytis cinerea strain B05-10 and Colletotrichum gloeosporioides. Drosomycin inhibited the growth of both fungi at 1.5 and $15 \mu \mathrm{M}$, respectively (Cohen et al., 2009). Another group demonstrated the efficiency of AFPs to combat planktonic fungi and biofilm formation. In a study using OSIP108, a Caenorhabditis elegans in vivo model was used to test synergic effects using different combinations of OSIP108 with Csf. The worms were infected with C. albicans and subsequently treated with $100 \mu \mathrm{M}$ OSIP108, $0.095 \mu \mathrm{M}$ Csf, and $100 \mu \mathrm{M}$ OSIP108 + $0.095 \mu \mathrm{M}$ Csf, and $0.6 \%$ DMSO (negative control) after 3, 5, and 7 days. The 
TABLE 5 | | Overview of different animal models for screening for antifungal drugs.

\begin{tabular}{|c|c|c|c|}
\hline Animal models & Candida sp. & Aspergillus sp. & Cryotococcus sp. \\
\hline Galleria mellonella (greater wax moth) & $\begin{array}{l}\text { Rowan et al., 2009; Lopez-Moya et al., } \\
\text { 2015; Souza et al., 2015; Aneja et al., } \\
\text { 2016; Ames et al., 2017; Gu et al., } \\
\text { 2018; Lu et al., } 2018\end{array}$ & $\begin{array}{l}\text { Alcazar-Fuoli et al., 2015; Forastiero } \\
\text { et al., 2015; Maurer et al., 2015; Ben } \\
\text { Yaakov et al., 2016; Ben Yaakov et al., } \\
2017\end{array}$ & $\begin{array}{l}\text { Sangalli-Leite et al., 2016; Palanco } \\
\text { et al., 2017; de Sá et al., } 2018\end{array}$ \\
\hline Bombyx mori (silkworm) & Uchida et al., 2016 & Nakamura et al., 2017 & $\begin{array}{l}\text { Ishii et al., 2016; Matsumoto et al., } \\
2017\end{array}$ \\
\hline Caenorhabditis elegans & $\begin{array}{l}\text { Delattin et al., 2013; Muhammed et al., } \\
\text { 2016; Graham et al., 2017; } \\
\text { Mohammad et al., 2018; Subramenium } \\
\text { et al., 2018; Sun et al., } 2018\end{array}$ & & $\begin{array}{l}\text { de Aguiar Cordeiro et al., 2016; } \\
\text { Thangamani et al., } 2017\end{array}$ \\
\hline Drosophila melanogaster & $\begin{array}{l}\text { Glittenberg et al., 2011; Zanette and } \\
\text { Kontoyiannis, } 2013\end{array}$ & Lionakis and Kontoyiannis, 2012 & \\
\hline Danio rerio Zebrafish larvae & & & Palanco et al., 2017 \\
\hline Mice & $\begin{array}{l}\text { López-García et al., 2005; Graham } \\
\text { et al., 2017; Li et al., 2017; Peters } \\
\text { et al., 2017; Wu et al., 2017; Dostert } \\
\text { et al., 2018; Singulani et al., 2017; } \\
\text { Lepak et al., 2018; Ci et al., } 2018\end{array}$ & $\begin{array}{l}\text { Ben-Ami et al., 2010; Kai et al., 2013; } \\
\text { Paulussen et al., } 2015\end{array}$ & Rathore et al., 2017; Nixon et al., 2018 \\
\hline Rats & $\begin{array}{l}\text { Bink et al., 2012; Kucharíková et al., } \\
\text { 2013; De Cremer et al., 2014; } \\
\text { Kucharíková et al., 2014; Li et al., 2014; } \\
\text { Cools et al., 2017b; Holtappels et al., } \\
2018\end{array}$ & & \\
\hline Guinea pigs & Maiolo et al., 2016 & $\begin{array}{l}\text { Wiederhold et al., 2015; Zhao et al., } \\
2015\end{array}$ & Kirkpatrick et al., 2007 \\
\hline Rabbit & & $\begin{array}{l}\text { Walsh et al., 1995; Petraitiene et al., } \\
2002\end{array}$ & \\
\hline
\end{tabular}

authors reported that OSIP108 alone did not present activity in C. albicans infected worms. However, the combination $100 \mu \mathrm{M}$ OSIP108 + $0.095 \mu \mathrm{M}$ Csf improved worms' survival. In accordance with these results, OSIP108 can be used for coating strategies in some medical devices, assisting in the fight against biofilm formation. The studies described above show that AFPs derived from plants are very efficient in inhibiting or controlling fungal biofilms tested in different in vivo models, demonstrating their therapeutic potential (Thevissen et al., 2007; Delattin et al., 2014).

Different groups of peptides have been tested by $\mathrm{Yu}$ et al. (2016). These authors have demonstrated the potential of four cathelicidins (cathelicidin-BF, Pc-CATH1, Cc-CATH2, CcCATH3) in combating C. albicans biofilm formation (Yu et al., 2016). The cathelicidins were tested in a murine oral candidiasis model using LL-37 and amphotericin B as control. Mice were infected by intramuscular injection and then infected by topical inoculation with $C$. albicans dilutions $(0.1 \mathrm{~mL})$ on the oral mucosa surface. The cathelicidin-BF inhibited C. albicans biofilm formation, demonstrating better results compared to other peptides. Similar results were also described by De Brucker et al. (2014) in in vitro tests using AS10 to inhibit fungal biofilm formation. As a result, AS10 was capable of inhibiting biofilm formation at $0.22 \mu \mathrm{M}$, and acted synergistically with amphotericin B and Csf against mature biofilms. In addition, this peptide did not exert a cytotoxic effect on mammalian cells.

Furthermore, synthetic peptides ( $\beta$-peptides) have shown promising antifungal and antibiofilm properties against
C. albicans. These AFPs act by reducing fungal metabolic activities and preventing or compromising biofilm formation (Delattin et al., 2014; Raman et al., 2014). The great activity of synthetic $\beta$-sheet peptides was also demonstrated by $\mathrm{Wu}$ et al. (2015). These authors tested the peptides (IKIK) $)_{2}-\mathrm{NH}_{2}$ and (IRIK) $)_{2}-\mathrm{NH}_{2}$ in vivo against fungal keratitis in comparison with the commercially available amphotericin $\mathrm{B}$ (Wu et al., 2015). They used contact lenses containing a layer of C. albicans biofilm, subsequently transferred onto the de-epithelia cornea surface of mice. The inoculum was maintained for $18 \mathrm{~h}$, and eye ulcers developed with a leathery, tough, raised surface. Treatment was performed with peptide 1 (3000 mg.L $\left.\mathrm{L}^{-1}\right)$, peptide 2 (3000 mg. $\mathrm{L}^{-1}$ ), amphotericin B (1000 mg. $\left.\mathrm{L}^{-1}\right)$ and water (control), and further applied topically as eye drops $(20 \mathrm{~mL})$ on the corneal surface. After treatment, the authors observed a significant decrease in keratitis infection, suggesting that synthetic $\beta$-sheet peptides are effective in removing keratitis-related fungal biofilms from mouse eyes.

Additionally to the previously mentioned in vitro experiments, the potential of EntV $\mathrm{V}^{68}$ was evaluated in two fungal infection models in which this peptide showed to be protective during C. albicans infection via inhibition of hyphal morphogenesis at low concentrations. The nematode infection model used C. elegans to evaluate C. albicans filamentation by microscopy. Thus, it was observed that, in the presence of $\operatorname{EntV}^{68}$ at subnanomolar concentrations $(100 \mathrm{nM}=0.0001 \mu \mathrm{M})$, the virulence of $C$. albicans in the nematodes was nullified. Furthermore, the authors suggest that $\operatorname{EntV}^{68}$ is effective 
in protecting C. elegans during C. albicans infection via inhibition of $C$. albicans hyphal morphogenesis (Graham et al., 2017). In murines (immunosuppressed Balb-C mice), the evaluated model was oropharyngeal candidiasis (OPC). The results obtained showed that, based on a treatment with $100 \mathrm{nM}(0.0001 \mu \mathrm{M})$ of $\mathrm{EntV}^{68}$, mice had a significant reduction in fungal cell invasion, showing once again the ability of this peptide to inhibit morphological differentiation (Graham et al., 2017). Other peptides tested in animal models against fungal strains and biofilms are summarized in Table 6.

\section{BIOTECHNOLOGICAL POTENTIAL}

In recent years, fungal infections have become a worldwide health problem (Brown et al., 2012; Gamaletsou et al., 2018). Fungal biofilm formation is nowadays increasingly reported in systemic, superficial and mucosal fungal infections (Duncan and O'Neil, 2013; Nett and Andes, 2015). In addition to that, therapeutic strategies are still scarce and show limited effectiveness (Chowdhary et al., 2017; Santos et al., 2017). Moreover, one of the ways to correlate the challenges of working with AFPs is by looking at the failures of working with AMPs. In both cases, one of the obstacles in developing such molecules as pharmaceuticals is the substantial activity loss under physiological saline concentrations (Kerenga et al., 2019). Some authors have reported additional disadvantages, including systemic and local toxicity, susceptibility to proteolysis, sensitization and allergy after repeated application, and high costs in discovering, screening and manufacturing these peptides (Koczulla and Bals, 2003; Gordon et al., 2005). However, there are promising advantages as well, including AFPs' broad-spectrum action (antibacterial, antifungal, antiviral), rapid action upon contact with the pathogen, potentially low levels of induced resistance, as well as anti-inflammatory and immunomodulatory activity (Koczulla and Bals, 2003; Gordon et al., 2005). After years without any innovation in chemical antifungal agents, the AFPs initiated a new prospect for fungal treatment (Duncan and O'Neil, 2013; Santos et al., 2017). The study of AFPs is an

TABLE 6 | Overview of antifungal peptides tested in vivo against free-floating fungi and biofilms.

\begin{tabular}{|c|c|c|}
\hline Peptides & AFP classes & References \\
\hline $\begin{array}{l}\text { hBD1hDB3, Psd1, } \\
\text { HsAFP1, RsAFP2, } \\
\text { NFAP2, }\end{array}$ & Defensins & $\begin{array}{l}\text { Martinez and Casadevall, 2006; } \\
\text { Pusateri et al., 2009; Delattin et al., } \\
\text { 2014; Gonçalves et al., 2017; Menzel } \\
\text { et al., 2017; Kovács et al., } 2018\end{array}$ \\
\hline LL-37, P318, AS10 & Cathelicidins & $\begin{array}{l}\text { Benincasa et al., 2006; De Brucker } \\
\text { et al., 2014; Yu et al., 2016; } \\
\text { Niemirowicz et al., 2017; Sun et al., } \\
2018\end{array}$ \\
\hline $\begin{array}{l}\text { Histatin-5, } \\
\text { Hst5 }_{4-15} \text { Spd }\end{array}$ & Histatins & Sung et al., 2008; Tati et al., 2014 \\
\hline $\begin{array}{l}\text { Tn-AFP, OSIPI08, } \\
\text { EntV68 }\end{array}$ & Unusual AFPs & $\begin{array}{l}\text { Gonçalves et al., 2017; Kovács et al., } \\
2018\end{array}$ \\
\hline$\beta$-peptides, mPE & Synthetic $\beta$-sheet & Raman et al., 2014; Wu et al., 2015 \\
\hline
\end{tabular}

emerging field, and recent works have focused on new strategies to improve their stability, safety, and efficacy (Kerenga et al., 2019). Moreover, an increasing number of studies have shown the advantages of combination therapies and drug delivery systems for AFPs' efficacy (Mahlapuu et al., 2016; Koo et al., 2017; Gomes et al., 2018; Revie et al., 2018).

According to the Food and Drug Administration (FDA), the number of approved bioactive peptides is growing. This rise is associated with the understanding of biofilm microenvironments, allowing the development of multitargeted therapeutic approaches to prevent biofilm formation and combat preformed biofilms, enhancing drug efficacy (Koo et al., 2017; Lee et al., 2019). Some AFPs have been proved to act synergically with conventional antifungals, improving the success of antifungal therapies (Cohen et al., 2009; De Brucker et al., 2014). Thus, AFPs have shown great efficiency against fungal biofilms, along with the lack of side effects that are recurrent in conventional antifungal treatments. Moreover, some AMPs are undergoing pre-clinical and clinical trials, including the treatment of infections related to contaminated catheters, topical formulations for acne, treatment of peritoneal infections caused by bacteria (e.g., pneumonia), as well as treatment of gingivitis and oral biofilms (Guaní-Guerra et al., 2010). However, to date, AFPs with fungal antibiofilm activity have not yet reached the market.

Therefore, in this review we described different applications for AFPs, with a core focus on antibiofilm properties toward fungi. This includes the use of AFPs as topical agents for the treatment of superficial vulvovaginal candidiasis (Kovács et al., 2018). Another application is against fungal keratitis, in which AFPs can be used as eye drops (Wu et al., 2015), as well as for oral administration (Yu et al., 2016). Furthermore, AFPs can be immobilized on medical devices (e.g., catheter, prosthesis and implants) to prevent fungal biofilm formation (De Brucker et al., 2014; Gonçalves et al., 2017). Besides that, nanoformulation strategies may allow the maintenance of AFPs stability and activity, thus improving the treatment's effectiveness by creating drug delivery systems (Batoni et al., 2011; Kovalainen et al., 2015; Mahlapuu et al., 2016; Cavalheiro and Teixeira, 2018; Dostert et al., 2018). Apart from their strong performance in the therapeutic area, AFPs can also be used in cosmetics (Bedoux et al., 2014; Rahnamaeian and Vilcinskas, 2015; Carvalho et al., 2016), diagnostics (Ribeiro et al., 2016; Young-Speirs et al., 2018), functional food and nutraceuticals (Gianfranceschi et al., 2018), vaccines (Nami et al., 2019), and in agriculture for pest control (Subbanna et al., 2019).

When combined with their activity against fungal biofilms, heat stability, $\mathrm{pH}$, degradation and proteolysis, we can provide a solid basis for the development of AFPs as antimicrobial therapeutic agents for clinical use. Their multifunctionality with respect to antifungal and antibacterial properties is particularly stimulating, as there is potential utility against polymicrobial infections. Taken together, all the findings highlighted in this review suggest the promising application of AFPs as new biomolecules in pre-clinical and clinical trials, reinforcing a 
growing movement in which bioactive peptides may assume a lead role in modern medicine and pharmaceutics.

\section{AUTHOR CONTRIBUTIONS}

$\mathrm{KO}, \mathrm{GR}, \mathrm{BM}$, and $\mathrm{MC}$ wrote the manuscript. $\mathrm{KO}$ and $\mathrm{MC}$ idealized and organized the figures. MC and $\mathrm{OF}$ corrected the manuscript. OF supervised and managed all authors.

\section{REFERENCES}

Aerts, A. M., Bammens, L., Govaert, G., Carmona-Gutierrez, D., Madeo, F., Cammue, B., et al. (2011). The antifungal plant defensin HsAFP1 from Heuchera sanguinea induces apoptosis in Candida albicans. Front. Microbiol. 2:47. doi: 10.3389/fmicb.2011.00047

Aerts, A. M., François, I. E. J. A., Cammue, B. P. A., and Thevissen, K. (2008). The mode of antifungal action of plant, insect and human defensins. Cell. Mol. Life Sci. 65, 2069-2079. doi: 10.1007/s00018-008-8035-0

Ajesh, K., and Sreejith, K. (2012). Cryptococcus laurentii biofilms: structure, development and antifungal drug resistance. Mycopathologia 174, 5-6. doi: 10.1007/s11046-012-9575-2

Alcazar-Fuoli, L., Buitrago, M., Gomez-Lopez, A., and Mellado, E. (2015). An alternative host model of a mixed fungal infection by azole susceptible and resistant Aspergillus spp. strains. Virulence 6, 376-384. doi: 10.1080/21505594. 2015.1025192

Ames, L., Duxbury, S., Pawlowska, B., Ho, H. L., Haynes, K., and Bates, S. (2017). Galleria mellonella as a host model to study Candida glabrata virulence and antifungal efficacy. Virulence 8, 1909-1917. doi: 10.1080/21505594.2017. 1347744

Aneja, B., Irfan, M., Kapil, C., Jairajpuri, M. A., Maguire, R., Kavanagh, K., et al. (2016). Effect of novel triazole-amino acid hybrids on growth and virulence of Candida species: in vitro and in vivo studies. Org. Biomol. Chem. 14, 1059910619. doi: 10.1039/c6ob01718e

Batoni, G., Maisetta, G., Lisa Brancatisano, F., Esin, S., and Campa, M. (2011). Use of antimicrobial peptides against microbial biofilms: advantages and limits. Curr. Med. Chem. 18, 256-279. doi: 10.2174/092986711794088399

Bedoux, G., Hardouin, K., Burlot, A. S., and Bourgougnon, N. (2014). Bioactive components from seaweeds: cosmetic applications and future development. Adv. Bot. Res. 71, 345-378. doi: 10.1016/B978-0-12-408062-1.00 012-3

Ben Yaakov, D., Rivkin, A., Mircus, G., Albert, N., Dietl, A. M., Kovalerchick, D., et al. (2016). Identification and characterization of haemofungin, a novel antifungal compound that inhibits the final step of haem biosynthesis. J. Antimicrob. Chemoter. 71, 946-952. doi: 10.1093/jac/dkv446

Ben Yaakov, D., Shadkchan, Y., Albert, N., Kontoyiannis, D. P., and Osherov, N. (2017). The quinoline bromoquinol exhibits broad-spectrum antifungal activity and induces oxidative stress and apoptosis in Aspergillus fumigatus. J. Antimicrob. Chemother. 72, 2263-2272. doi: 10.1093/jac/dkx117

Ben-Ami, R., Lewis, R. E., Leventakos, K., Latgé, J. P., and Kontoyiannis, D. P. (2010). Cutaneous model of invasive aspergillosis. Antimicrob. Agents Chemother. 54, 1848-1854. doi: 10.1128/AAC.01504-09

Benincasa, M., Scocchi, M., Pacor, S., Tossi, A., Nobili, D., Basaglia, G., et al. (2006). Fungicidal activity of five cathelicidin peptides against clinically isolated yeasts. J. Antimicrob. Chemother. 58, 950-959. doi: 10.1093/jac/dkl382

Bink, A., Kucharíková, S., Neirinck, B., Vleugels, J., Van Dijck, P., Cammue, B. P., et al. (2012). The nonsteroidal antiinflammatory drug diclofenac potentiates the in vivo activity of caspofungin against Candida albicans biofilms. J. Infect. Dis. 206, 1790-1797. doi: 10.1093/infdis/jis594

Brewer, D., Hunter, H., and Lajoie, G. (1998). NMR studies of the antimicrobial salivary peptides histatin 3 and histatin 5 in aqueous and nonaqueous solutions. Biochem. Cell Biol. 76, 247-256. doi: 10.1139/098-066

Brown, G. D., Denning, D. W., Gow, N. A., Levitz, S. M., Netea, M. G., and White, T. C. (2012). Hidden killers: human fungal infections. Sci. Transl. Med. 4:165rv13. doi: 10.1126/scitranslmed.3004404

\section{FUNDING}

This work was supported by grants from the Fundação de Apoio à Pesquisa do Distrito Federal (FAPDF), Coordenação de Aperfeiçoamento de Pessoal de Nível Superior (CAPES), Conselho Nacional de Desenvolvimento e Tecnológico (CNPq), and Fundação de Apoio ao Desenvolvimento do Ensino, Ciência e Tecnologia do Estado de Mato Grosso do Sul (FUNDECT), Brazil.

Burrows, L. L., Stark, M., Chan, C., Glukhov, E., Sinnadurai, S., and Deber, C. M. (2006). Activity of novel non-amphipathic cationic antimicrobial peptides against Candida species. J. Antimicrob. Chemother. 57, 899-907. doi: 10.1093/ jac/dkl056

Capilla, J., Clemons, K. V., and Stevens, D. A. (2007). Animal models: an important tool in mycology. Med. Mycol. 45, 657-684. doi: 10.1080/13693780701644140

Carvalho, I. T., Estevinho, B. N., and Santos, L. (2016). Application of microencapsulated essential oils in cosmetic and personal healthcare productsa review. Inter. J. Cosm. Sci. 38, 109-119. doi: 10.1111/ics.12232

Cavalheiro, M., and Teixeira, M. C. (2018). Candida biofilms: threats, challenges, and promising strategies. Front. Med. 5:28. doi: 10.3389/fmed.2018.00028

Čeřovský, V., Buděšínský, M., Hovorka, O., Cvačka, J., Voburka, Z., Slaninová, J., et al. (2009). Lasioglossins: three novel antimicrobial peptides from the venom of the eusocial bee Lasioglossum laticeps (Hymenoptera: Halictidae). ChemBioChem 10, 2089-2099. doi: 10.1002/cbic.200900133

Chairatana, P., Chiang, I. L., and Nolan, E. M. (2017). Human $\alpha$-defensin 6 selfassembly prevents adhesion and suppresses virulence traits of Candida albicans. Biochemistry 56, 1033-1041. doi: 10.1021/acs.biochem.6b01111

Cho, J., and Lee, D. G. (2011). Oxidative stress by antimicrobial peptide pleurocidin triggers apoptosis in Candida albicans. Biochimie 93, 1873-1879. doi: 10.1016/j. biochi.2011.07.011

Chowdhary, A., Sharma, C., and Meis, J. F. (2017). Azole-resistant aspergillosis: epidemiology, molecular mechanisms, and treatment. J. Infec. Dis. 216(Suppl. 3), S436-S444. doi: 10.1093/infdis/jix210

Ci, T., Yuan, L., Bao, X., Hou, Y., Wu, H., Sun, H., et al. (2018). Development and anti-Candida evaluation of the vaginal delivery system of amphotericin B nanosuspension-loaded thermogel. J. Drug Target 26, 829-839. doi: 10.1080/ 1061186X.2018.1434660

Cohen, L., Moran, Y., Sharon, A., Segal, D., Gordon, D., and Gurevitz, M. (2009). Drosomycin, an innate immunity peptide of Drosophila melanogaster, interacts with the fly voltage-gated sodium channel. J. Biol. Chem. 284, 23558-23563. doi: 10.1074/jbc.M109.023358

Cools, T. L., Struyfs, C., Cammue, B. P., and Thevissen, K. (2017a). Antifungal plant defensins: increased insight in their mode of action as a basis for their use to combat fungal infections. Future Microbiol. 12, 441-454. doi: 10.2217/ fmb-2016-0181

Cools, T. L., Struyfs, C., Drijfhout, J. W., Kucharíková, S., Lobo Romero, C., Van Dijck, P., et al. (2017b). A linear 19-mer plant defensin-derived peptide acts synergistically with caspofungin against Candida albicans biofilms. Front. Microbiol. 8:2051. doi: 10.3389/fmicb.2017.02051

de Aguiar Cordeiro, R., de Jesus Evangelista, A. J., Serpa, R., de Farias Marques, F. J., de Melo, C. V. S., de Oliveira, J. S., et al. (2016). Inhibition of heat-shock protein 90 enhances the susceptibility to antifungals and reduces the virulence of Cryptococcus neoformans/Cryptococcus gattii species complex. Microbiology 162, 309-317. doi: 10.1099/mic.0.000222

De Brucker, K., Delattin, N., Robijns, S., Steenackers, H., Verstraeten, N. Landuyt, B., et al. (2014). Derivatives of the mouse cathelicidin-related antimicrobial peptide (CRAMP) inhibit fungal and bacterial biofilm formation. Antimicrob. Agents Chemother. 58, 5395-5404. doi: 10.1128/aac.03045- 14

De Coninck, B., Carron, D., Tavormina, P., Willem, L., Craik, D. J., Vos, C., et al. (2013). Mining the genome of Arabidopsis thaliana as a basis for the identification of novel bioactive peptides involved in oxidative stress tolerance. J. Exp. Bot. 64, 5297-5307. doi: 10.1093/jxb/ert295

De Cremer, K., Delattin, N., De Brucker, K., Peeters, A., Kucharíková, S., Gerits, E., et al. (2014). Oral administration of the broad-spectrum antibiofilm 
compound toremifene inhibits Candida albicans and Staphylococcus aureus biofilm formation in vivo. Antimicrob. Agents Chemother. 58, 7606-7610. doi: 10.1128/AAC.03869-14

De Lucca, A. J., and Walsh, T. J. (1999). Antifungal peptides: novel therapeutic compounds against emerging pathogens. Antimicrob. Agents Chemother. 43, 1-11. doi: 10.1128/AAC.03869-1

de Sá, N. P., de Barros, P. P., Junqueira, J. C., Vaz, J. A., de Oliveira, R. B., Rosa, C. A., et al. (2018). Thiazole derivatives act on virulence factors of Cryptococcus spp. Med. Mycol. 1, 84-91. doi: 10.1093/mmy/myx158

De Zoysa, G. H., Cameron, A. J., Hegde, V. V., Raghothama, S., and Sarojini, V. (2015). Antimicrobial peptides with potential for biofilm eradication: synthesis and structure activity relationship studies of battacin peptides. J. Med. Chem. 58, 625-639. doi: 10.1021/jm501084q

De Zoysa, G. H., Glossop, H. D., and Sarojini, V. (2018). Unexplored antifungal activity of linear battacin lipopeptides against planktonic and mature biofilms of C. albicans. Eur. J. Med. Chem. 146, 344-353. doi: 10.1016/j.ejmech.2018.01.023

Delattin, N., De Brucker, K., Craik, D. J., Cheneval, O., Fröhlich, M., Veber, M., et al. (2014). The plant-derived decapeptide OSIP108 interferes with Candida albicans biofilm formation without affecting cell viability. Antimicrob. Agents Chemother. 58, 2647-2656. doi: 10.1128/AAC.01274-13

Delattin, N., De Brucker, K., De Cremer, K., Pa Cammue, B., and Thevissen, K. (2017). Antimicrobial peptides as a strategy to combat fungal biofilms. Curr. Top. Med. Chem. 17, 604-612. doi: 10.2174/1568026616666160713142228

Delattin, N., De Brucker, K., Vandamme, K., Meert, E., Marchand, A., Chaltin, P., et al. (2013). Repurposing as a means to increase the activity of amphotericin $\mathrm{B}$ and caspofungin against Candida albicans biofilms. J. Antimicrob. Chemoter. 69, 1035-1044. doi: 10.1093/jac/dkt449

Dhople, V., Krukemeyer, A., and Ramamoorthy, A. (2006). The human betadefensin-3, an antibacterial peptide with multiple biological functions. Biochim. Biophys. Acta Biomembr. 1758, 1499-1512. doi: 10.1016/j.bbamem.2006.07.007

Di Luca, M., Maccari, G., and Nifosì, R. (2014). Treatment of microbial biofilms in the post-antibiotic era: prophylactic and therapeutic use of antimicrobial peptides and their design by bioinformatics tools. Pathog. Dis. 70, 257-270. doi: 10.1111/2049-632x.12151

Dijck, P. V., Sjollema, J., Cammue, B. P., Lagrou, K., Berman, J., d’Enfert, C., et al. (2018). Methodologies for in vitro and in vivo evaluation of efficacy of antifungal and antibiofilm agents and surface coatings against fungal biofilms. Microb. Cell. 5, 300-326. doi: 10.15698/mic2018.07.638

Dongari-Bagtzoglou, A., Kashleva, H., Dwivedi, P., Diaz, P., and Vasilakos, J. (2009). Characterization of mucosal Candida albicans biofilms. PLoS One 4:e7967. doi: 10.1371/journal.pone.0007967

Dostert, M., Belanger, C. R., and Hancock, R. E. W. (2018). Design and assessment of anti-biofilm peptides: steps toward clinical application. J. Innate Immun. 11, 193-204. doi: 10.1159/000491497

Douglas, L. J. (2002). Medical importance of biofilms in Candida infections. Rev. Iberoam. Micol. 19, 139-143.

Duncan, V. M., and O’Neil, D. A. (2013). Commercialization of antifungal peptides. Fungal Biol. Rev. 26, 156-165. doi: 10.1016/j.fbr.2012.11.001

Faruck, M. O., Yusof, F., and Chowdhury, S. (2016). An overview of antifungal peptides derived from insect. Peptides 80, 80-88. doi: 10.1016/j.peptides.2015. 06.001

Fjell, C. D., Hiss, J. A., Hancock, R. E., and Schneider, G. (2012). Designing antimicrobial peptides: form follows function. Nat. Rev. Drug Discov. 11, 37-51. doi: $10.1038 / \mathrm{nrd} 3591$

Forastiero, A., Bernal-Martínez, L., Mellado, E., Cendejas, E., and Gomez-Lopez, A. (2015). In vivo efficacy of voriconazole and posaconazole therapy in a novel invertebrate model of Aspergillus fumigatus infection. Int. J. Antimicrob. Agents 46, 511-517. doi: 10.1016/j.ijantimicag.2015.07.007

Gamaletsou, M. N., Walsh, T. J., and Sipsas, N. V. (2018). Invasive fungal infections in patients with hematological malignancies: emergence of resistant pathogens and new antifungal therapies. Turk. J. Haematol. 35, 1-11. doi: 10.4274/tjh.2018. 0007

Garcia-Sanchez, S. S., Aubert, S., Iraqui, I., Janbon, G., Ghigo, J. M., and d'Enfert, C. (2004). Candida albicans biofilms: a developmental state associated with specific and stable gene expression patterns. Eukaryot. Cell 3, 536-545. doi: 10.1128/EC.3.2.536-545.2004

Gennaro, R., and Zanetti, M. (2000). Structural features and biological activities of the cathelicidin-derived antimicrobial peptides. Biopolymers 55, 31-49.
Gianfranceschi, G. L., Gianfranceschi, G., Quassinti, L., and Bramucci, M. (2018). Biochemical requirements of bioactive peptides for nutraceutical efficacy. J. Funct. Foods 47, 252-263. doi: 10.1016/j.jff.2018.05.034

Giles, C., Lamont-Friedrich, S. J., Michl, T. D., Griesser, H. J., and Coad, B. R. (2018). The importance of fungal pathogens and antifungal coatings in medical device infections. Biotechnol. Adv. 36, 264-280. doi: 10.1016/j.biotechadv.2017. 11.010

Glittenberg, M. T., Silas, S., MacCallum, D. M., Gow, N. A., and Ligoxygakis, P. (2011). Wild-type Drosophila melanogaster as an alternative model system for investigating the pathogenicity of Candida albicans. Dis. Models Mech. 4, 504-514. doi: 10.1242/dmm.006619

Gomes, B., Augusto, M. T., Felício, M. R., Hollmann, A., Franco, O. L., Gonçalves, S., et al. (2018). Designing improved active peptides for therapeutic approaches against infectious diseases. Biotech. Adv. 36, 415-429. doi: 10.1016/j.biotechadv. 2018.01.004

Gonçalves, S., Silva, P. M., Felício, M. R., de Medeiros, L. N., Kurtenbach, E., and Santos, N. C. (2017). Psd1 effects on Candida albicans planktonic cells and biofilms. Front. Cell. Infect. Microbiol. 7:249. doi: 10.3389/fcimb.2017.00249

Gordon, Y. J., Romanowski, E. G., and McDermott, A. M. (2005). A review of antimicrobial peptides and their therapeutic potential as anti-infective drugs. Curr. Eye Res. 30, 505-515. doi: 10.1080/02713680590968637

Graham, C. E., Cruz, M. R., Garsin, D. A., and Lorenz, M. C. (2017). Enterococcus faecalis bacteriocin EntV inhibits hyphal morphogenesis, biofilm formation, and virulence of Candida albicans. Proc. Natl. Acad. Sci. U.S.A. 114, 4507-4512. doi: 10.1073/pnas.1620432114

$\mathrm{Gu}, \mathrm{W} ., \mathrm{Yu}, \mathrm{Q} ., \mathrm{Yu}, \mathrm{C}$, and Sun, S. (2018). In vivo activity of fluconazole/tetracycline combinations in Galleria mellonella with resistant Candida albicans infection. J. Glob. Antimicrob. Resist. 13, 74-80. doi: 10.1016/j.jgar.2017.11.011

Guaní-Guerra, E., Santos-Mendoza, T., Lugo-Reyes, S. O., and Terán, L. M. (2010). Antimicrobial peptides: general overview and clinical implications in human health and disease. J. Clin. Immunol. 135, 1-11. doi: 10.1016/j.clim.2009.12.004

Gulati, M., and Nobile, C. J. (2016). Candida albicans biofilms: development, regulation, and molecular mechanisms. Microb. Infect. 18, 310-321. doi: 10. 1016/j.micinf.2016.01.002

Hall-Stoodley, L., Costerton, J. W., and Stoodley, P. (2004). Bacterial biofilms: from the natural environment to infectious diseases. Nat. Rev. Microbiol. 2, 95-108. doi: $10.1038 /$ nrmicro821

Harriott, M., Lilly, E. A., Rodriguez, T. E., Fidel, P. L. Jr., and Noverr, M. C. (2010). Candida albicans forms biofilms on the vaginal mucosa. Microbiology 156, 3635-3644. doi: 10.1099/mic.0.039354-0

Hohl, T. M. (2014). Overview of vertebrate animal models of fungal infection. J. Immunol. Methods 410, 100-112. doi: 10.1016/j.jim.2014.03.022

Holtappels, M., Swinnen, E., De Groef, L., Wuyts, J., Moons, L., Lagrou, K., et al. (2018). Antifungal activity of oleylphosphocholine on in vitro and in vivo Candida albicans biofilms. Antimicrob. Agents Chemother. 62:e01767-17. doi: 10.1128/AAC.01767-17

Ishii, M., Matsumoto, Y., and Sekimizu, K. (2016). Usefulness of silkworm as a host animal for understanding pathogenicity of Cryptococcus neoformans. Drug Discov. Ther. 10, 9-13. doi: 10.5582/ddt.2016.01015

Jarczak, J., Kościuczuk, E. M., Lisowski, P., Strzałkowska, N., Jóźwik, A., Horbańczuk, J., et al. (2013). Defensins: natural component of human innate immunity. Hum. Immunol. 74, 1069-1079. doi: 10.1016/j.humimm.2013. 05.008

Kai, H., Yamashita, M., Nakamura, I., Yoshikawa, K., Nitta, K., Watanabe, M., et al. (2013). Synergistic antifungal activity of KB425796-C in combination with micafungin against Aspergillus fumigatus and its efficacy in murine infection models. J. Antibiot. 66, 479-484. doi: 10.1038/ja.2013.57

Kaur, S., and Singh, S. (2013). Biofilm formation by Aspergillus fumigatus. Med. Mycol. 52, 2-9. doi: 10.3109/13693786.2013.819592

Kerenga, B. K., McKenna, J. A., Harvey, P. J., Quimbar, P., Garcia, D., Lay, F. T., et al. (2019). Salt-tolerant antifungal and antibacterial activities of the corn defensin ZmD32. Front. Microbiol. 10:795. doi: 10.3389/fmicb.2019.00795

Kirkpatrick, W. R., Najvar, L. K., Bocanegra, R., Patterson, T. F., and Graybill, J. R. (2007). New guinea pig model of Cryptococcal meningitis. Antimicrob. Agent Chemother. 51, 3011-3013. doi: 10.1128/AAC.00085-07

Kočendová, J., Vaňková, E., Volejníková, A., Nešuta, O., Buděšínský, M., Socha, O., et al. (2019). Antifungal activity of analogues of antimicrobial peptides isolated 
from bee venoms against vulvovaginal Candida spp. FEMS Yeast Res. 19:foz013. doi: 10.1093/femsyr/foz013

Koczulla, A. R., and Bals, R. (2003). Antimicrobial peptides. Drugs 63, 389-406. doi: 10.2165/00003495-200363040-00005

Konopka, K., Dorocka-Bobkowska, B., Gebremedhin, S., and Düzgüneş, N. (2010). Susceptibility of Candida biofilms to histatin 5 and fluconazole. Antonie van Leeuwenhoek 97, 413-417. doi: 10.1007/s10482-010-9417-5

Koo, H., Allan, R. N., Howlin, R. P., Stoodley, P., and Hall-Stoodley, L. J. N. R. M. (2017). Targeting microbial biofilms: current and prospective therapeutic strategies. Nat. Rev. Microbiol. 5, 740-755. doi: 10.1038/nrmicro.2017.99

Kovács, R., Holzknecht, J., Hargitai, Z., Papp, C., Farkas, A., Borics, A., et al. (2018). In vivo applicability of Neosartorya fischeri antifungal protein 2 (NFAP2) in treatment of vulvovaginal candidiasis. Antimicrob. Agents Chemother. 63:e01777-18. doi: 10.1128/AAC.01777-18

Kovalainen, M., Mönkäre, J., Riikonen, J., Pesonen, U., Vlasova, M., Salonen, J., et al. (2015). Novel delivery systems for improving the clinical use of peptides. Pharmacol. Rev. 67, 541-561. doi: 10.1124/pr.113.008367

Krishnakumari, V., Rangaraj, N., and Nagaraj, R. (2009). Antifungal activities of human beta-defensins HBD-1 to HBD-3 and their C-terminal analogs Phd1 to Phd3. Antimicrob. Agents Chemother. 53, 256-260. doi: 10.1128/AAC.00470-08

Kucharíková, S., Neirinck, B., Sharma, N., Vleugels, J., Lagrou, K., and Van Dijck, P. (2014). In vivo Candida glabrata biofilm development on foreign bodies in a rat subcutaneous model. J. Antimicrob. Chemother. 70, 846-856. doi: 10.1093/ $\mathrm{jac} / \mathrm{dku} 447$

Kucharíková, S., Sharma, N., Spriet, I., Maertens, J., Van Dijck, P., and Lagrou, K. (2013). Activity of systemically administered echinocandins against in vivo mature Candida albicans biofilms developed in a rat subcutaneous model. Antimicrob. Agents Chemother. 57, 2365-2368. doi: 10.1128/AAC.02288-12

Lay, F., and Anderson, M. (2005). Defensins-components of the innate immune system in plants. Curr. Protein Pept. Sci. 6, 85-101. doi: 10.2174/ 1389203053027575

Lee, M. R., Raman, N., Ortiz-Bermudez, P., Lynn, D. M., and Palecek, S. P. (2019). 14-Helical beta-peptides elicit toxicity against $C$. albicans by forming pores in the cell membrane and subsequently disrupting intracellular organelles. Cell Chem. Biol. 26, 289-299. doi: 10.1016/j.chembiol.2018.11.002

Lepak, A. J., Zhao, M., VanScoy, B., Ambrose, P. G., and Andes, D. R. (2018). Pharmacodynamics of a long-acting echinocandin, CD101, in a neutropenic invasive-candidiasis murine model using an extended-interval dosing design. Antimicrob. Agents Chemother. 62:e02154-17. doi: 10.1128/AAC.02154-17

Li, D.-D., Zhao, L. X., Mylonakis, E., Hu, G. H., Zou, Y., Huang, T. K., et al. (2014). In vitro and in vivo activity of pterostilbene against Candida albicans biofilms. Antimicrob. Agents Chemother. 58, 2344-2355. doi: 10.1128/AAC.01583-13

Li, R., Zhang, L., Zhang, H., Yi, Y., Wang, L., Chen, L., et al. (2017). Protective effect of a novel antifungal peptide derived from human chromogranin a on the immunity of mice infected with Candida krusei. Exp. Ther. Med. 13, 2429-2434. doi: 10.3892/etm.2017.4290

Lim, S.-M., Ahn, K. B., Kim, C., Kum, J. W., Perinpanayagam, H., Gu, Y., et al. (2016). Antifungal effects of synthetic human $\beta$-defensin 3C15 peptide. Restor. Dent. Endod. 43, 1857-1861. doi: 10.5395/rde.2016. 41.2.91

Lionakis, M. S., and Kontoyiannis, D. P. (2012). Drosophila melanogaster as a model organism for invasive aspergillosis. In host-fungus interactions. Methods Mol. Biol. 845, 455-468. doi: 10.1007/978-1-61779-539-8_32

Lionakis, M. S., and Levitz, S. M. (2018). Host control of fungal infections: lessons from basic studies and human cohorts. Ann. Rev. Immunol. 36, 157-191. doi: 10.1146/annurev-immunol-042617-053318

López-García, B., Lee, P. H., Yamasaki, K., and Gallo, R. L. (2005). Anti-fungal activity of cathelicidins and their potential role in Candida albicans skin infection. J. Invest. Dermatol. 125, 108-115. doi: 10.1111/j.0022-202X.2005. 23713.x

Lopez-Moya, F., Colom-Valiente, M. F., Martinez-Peinado, P., Martinez-Lopez, J. E., Puelles, E., Sempere-Ortells, J. M., et al. (2015). Carbon and nitrogen limitation increase chitosan antifungal activity in Neurospora crassa and fungal human pathogens. Fungal Biol. 119, 154-169. doi: 10.1016/j.funbio.2014.12.003

Lu, M., Yu, C., Cui, X., Shi, J., Yuan, L., and Sun, S. (2018). Gentamicin synergises with azoles against drug-resistant Candida albicans. Int. J. Antimicrob. Agents 51, 107-114. doi: 10.1016/j.ijantimicag.2017.09.012
Mahlapuu, M., Håkansson, J., Ringstad, L., and Björn, C. (2016). Antimicrobial peptides: an emerging category of therapeutic agents. Front. Cell. Infect. Microbiol. 6:194. doi: 10.3389/fcimb.2016.00194

Maiolo, E. M., Oliva, A., Tafin, U. F., Perrotet, N., Borens, O., and Trampuz, A. (2016). Antifungal activity against planktonic and biofilm Candida albicans in an experimental model of foreign-body infection. J. Infect. 72, 386-392. doi: 10.1016/j.jinf.2015.12.008

Mandal, S. M., Migliolo, L., Franco, O. L., and Ghosh, A. K. (2011). Identification of an antifungal peptide from Trapa natans fruits with inhibitory effects on Candida tropicalis biofilm formation. Peptides 32, 1741-1747. doi: 10.1016/j. peptides.2011.06.020

Martinez, L. R., and Casadevall, A. (2006). Cryptococcus neoformans cells in biofilms are less susceptible than planktonic cells to antimicrobial molecules produced by the innate immune system. Infect. Immun. 74, 6118-6123. doi: 10.1128/IAI.00995-06

Matejuk, A., Leng, Q., Begum, M. D., Woodle, M. C., Scaria, P., Chou, S. T., et al. (2010). Peptide-based antifungal therapies against emerging infections. Drugs Future 35:197. doi: 10.1358/dof.2010.035.03.1452077

Matsumoto, Y., Ishii, M., Shimizu, K., Kawamoto, S., and Sekimizu, K. (2017). A silkworm infection model to evaluate antifungal drugs for cryptococcosis. Med. Mycol. J. 112, 138-146. doi: 10.1111/j.1365-2672.2011.05186.x

Maurer, E., Browne, N., Surlis, C., Jukic, E., Moser, P., Kavanagh, K., et al. (2015). Galleria mellonella as a host model to study Aspergillus terreus virulence and amphotericin B resistance. Virulence 6, 591-598. doi: 10.1080/21505594.2015. 1045183

Mendes, M. A., de Souza, B. M., Marques, M. R., and Palma, M. S. (2004). Structural and biological characterization of two novel peptides from the venom of the neotropical social wasp Agelaia pallipes pallipes. Toxicon 44, 67-74. doi: 10. 1016/j.toxicon.2004.04.009

Menzel, L. P., Chowdhury, H. M., Masso-Silva, J. A., Ruddick, W., Falkovsky, K., Vorona, R., et al. (2017). Potent in vitro and in vivo antifungal activity of a small molecule host defense peptide mimic through a membrane-active mechanism. Sci. Rep. 7, 1-10. doi: 10.1038/s41598-017-04462-6

Moffa, E. B., Mussi, M., Xiao, Y., Garrido, S. S., Machado, M. A., Giampaolo, E. T., et al. (2015). Histatin 5 inhibits adhesion of C. albicans to reconstructed human oral epithelium. Front. Microbiol. 6:885. doi: 10.3389/fmicb.2015.00885

Mohammad, H., Elghazawy, N. H., Eldesouky, H. E., Hegazy, Y. A., Younis, W., Avrimova, L., et al. (2018). Discovery of a novel dibromoquinoline compound exhibiting potent antifungal and antivirulence activity that targets metal ion homeostasis. ACS Infect. Dis. 4, 403-414. doi: 10.1021/acsinfecdis.7b0 0215

Muhammed, M., Arvanitis, M., and Mylonakis, E. (2016). Whole animal HTS of small molecules for antifungal compounds. Expert. Opin. Drugs Discov. 11, 177-184. doi: 10.1517/17460441.2016.1122591

Nakamura, I., Kanasaki, R., Yoshikawa, K., Furukawa, S., Fujie, A., Hamamoto, H., et al. (2017). Discovery of a new antifungal agent ASP2397 using a silkworm model of Aspergillus fumigatus infection. J. Antibiot. 70, 41-44. doi: 10.1038/ja. 2016.106

Nami, S., Aghebati-Maleki, A., Morovati, H., and Aghebati-Maleki, L. (2019). Current antifungal drugs and immunotherapeutic approaches as promising strategies to treatment of fungal diseases. Biomed. Pharmacother. 110, 857-868. doi: 10.1016/j.biopha.2018.12.009

Nett, J. E., and Andes, D. (2015). Fungal biofilms: in vivo models for discovery of anti-biofilm drugs. Microbiol. Spectr. 3, 1-25. doi: 10.1128/microbiolspec.MB0008-2014

Nett, J. E., Marchillo, K., Spiegel, C. A., and Andes, D. R. (2010). Development and validation of an in vivo Candida albicans biofilm denture model. Infect. Immun. 78, 3650-3659. doi: 10.1128/IAI.00480-10

Niemirowicz, K., Durnaś, B., Tokajuk, G., Piktel, E., Michalak, G., Gu, X., et al. (2017). Formulation and candidacidal activity of magnetic nanoparticles coated with cathelicidin LL-37 and ceragenin CSA-13. Sci. Rep. 7, 1-12. doi: 10.1038/ s41598-017-04653-1

Nixon, G. L., McEntee, L., Johnson, A., Farrington, N., Whalley, S., Livermore, J., et al. (2018). Pharmacodynamics of flubendazole for cryptococcal meningoencephalitis: repurposing and reformulation of an anti-parasitic agent for a neglected fungal disease. Antimicrob. Agents Chemother. 62:e1909-17. doi: 10.1128/AAC.01909-17 
Oppenheim, F., Xu, T., McMillian, F. M., Levitz, S. M., Diamond, R. D., Offner, G. D., et al. (1988). Histatins, a novel family of histidine-rich proteins in human parotid secretion. Isolation, characterization, primary structure, and fungistatic effects on Candida albicans. J. Biol. Chem. 263, 7472-7477.

Osborn, R. W., De Samblanx, G. W., Thevissen, K., Goderis, I., Torrekens, S., Van Leuven, F., et al. (1995). Isolation and characterisation of plant defensins from seeds of Asteraceae, Fabaceae, Hippocastanaceae and Saxifragaceae. FEBS Lett. 368, 257-262. doi: 10.1016/0014-5793(95)00666-W

Palanco, A. C., Lacorte Singulani, J. D., Costa-Orlandi, C. B., Gullo, F. P., Strohmayer Lourencetti, N. M., Gomes, P. C., et al. (2017). Activity of $3^{\prime}$-hydroxychalcone against Cryptococcus gattii and toxicity, and efficacy in alternative animal models. Future Microbiol. 12, 1123-1134. doi: 10.2217/fmb2017-0062

Paris, S., Wolgin, M., Kielbassa, A. M., Pries, A., and Zakrzewicz, A. (2009). Gene expression of human beta-defensins in healthy and inflamed human dental pulps. J. Endodon. 35, 520-523. doi: 10.1016/j.joen.2008.12.015

Parisi, K., Shafee, T. M. A., Quimbar, P., van der Weerden, N. L., Bleackley, M. R., and Anderson, M. A. (2019). The evolution, function and mechanisms of action for plant defensins. Semin. Cell Dev. Biol. 88, 107-118. doi: 10.1016/j.semcdb. 2018.02.004

Paulone, S., Ardizzoni, A., Tavanti, A., Piccinelli, S., Rizzato, C., Lupetti, A., et al. (2017). The synthetic killer peptide KP impairs Candida albicans biofilm in vitro. PLoS One 12:e181278. doi: 10.1371/journal.pone.0181278

Paulussen, C., Boulet, G., Bosschaerts, T., Cos, P., Fortin, A., and Maes, L. (2015). Efficacy of oleylphosphocholine (Ol PC) in vitro and in a mouse model of invasive aspergillosis. Mycoses 58, 127-132. doi: 10.1111/myc.12286

Perlin, D. S., Rautemaa-Richardson, R., and Alastruey-Izquierdo, A. (2017). The global problem of antifungal resistance: prevalence, mechanisms, and management. Lancet Infect. Dis. 17, e383-e392. doi: 10.1016/S1473-3099(17) 30316-X

Peters, B. M., Luna-Tapia, A., Tournu, H., Rybak, J. M., Rogers, P. D., and Palmer, G. E. (2017). An azole-tolerant endosomal trafficking mutant of Candida albicans is susceptible to azole treatment in a mouse model of vaginal candidiasis. Antimicrob. Agents Chemother. 61:e00084-17. doi: 10.1128/AAC. 00084- 17

Petraitiene, R., Petraitis, V., Groll, A. H., Sein, T., Schaufele, R. L., Francesconi, A., et al. (2002). Antifungal efficacy of caspofungin (MK-0991) in experimental pulmonary aspergillosis in persistently neutropenic rabbits: pharmacokinetics, drug disposition, and relationship to galactomannan antigenemia. Antimicrob. Agents Chemother. 46, 12-23. doi: 10.1128/AAC.46.1.12-23.2002

Pusateri, C. R., Monaco, E. A., and Edgerton, M. (2009). Sensitivity of Candida albicans biofilm cells grown on denture acrylic to antifungal proteins and chlorhexidine. Arch. Oral Biol. 54, 588-594. doi: 10.1016/j.archoralbio.2009. 01.016

Qian, C.-D., Wu, X. C., Teng, Y., Zhao, W. P., Li, O., Fang, S. G., et al. (2012). Battacin (Octapeptin B5), a new cyclic lipopeptide antibiotic from Paenibacillus tianmuensis active against multidrug-resistant Gram-negative bacteria. Antimicrob. Agents Chemother. 56, 1458-1465. doi: 10.1128/AAC. 05580-11

Rahnamaeian, M., and Vilcinskas, A. (2015). Short antimicrobial peptides as cosmetic ingredients to deter dermatological pathogens. Appl. Microbiol. Biotechnol. 99, 8847-8855. doi: 10.1007/s00253-015-6926-1

Raman, N., Lee, M. R., Palecek, S. P., and Lynn, D. M. (2014). Polymer multilayers loaded with antifungal $\beta$-peptides kill planktonic Candida albicans and reduce formation of fungal biofilms on the surfaces of flexible catheter tubes. J. Control. Release 191, 54-62. doi: 10.1016/j.jconrel.2014. 05.026

Rathore, S. S., Isravel, M., Vellaisamy, S., Chellappan, D. R., Cheepurupalli, L., Raman, T., et al. (2017). Exploration of antifungal and immunomodulatory potentials of a furanone derivative to rescue disseminated cryptococosis in mice. Sci. Rep. 7, 1-14. doi: 10.1038/s41598-017-15 500-8

Rautenbach, M., Troskie, A. M., and Vosloo, J. A. (2016). Antifungal peptides: to be or not to be membrane active. Biochimie 130, 132-145. doi: 10.1016/j.biochi. 2016.05.013

Revie, N. M., Iyer, K. R., Robbins, N., and Cowen, L. E. (2018). Antifungal drug resistance: evolution, mechanisms and impact. Curr. Opin. Microbiol. 45, 70-76. doi: 10.1016/j.mib.2018.02.005
Ribeiro, S. M., Felicio, M. R., Boas, E. V., Goncalves, S., Costa, F. F., Samy, R. P., et al. (2016). New frontiers for anti-biofilm drug development. Pharmacol. Therap. 160, 133-144. doi: 10.1016/j.pharmthera.2016.02.006

Rodrigues, C. F., Rodrigues, M. E., and Henriques, M. (2018). Susceptibility of Candida glabrata biofilms to echinocandins: alterations in the matrix composition. Biofouling 34, 569-578. doi: 10.1080/08927014.2018.1472244

Rossignol, T., Kelly, B., Dobson, C., and d'Enfert, C. (2011). Endocytosis-mediated vacuolar accumulation of the human ApoE apolipoprotein-derived ApoEdpL$\mathrm{W}$ antimicrobial peptide contributes to its antifungal activity in Candida albicans. Antimicrob. Agents Chemother. 55, 4670-4681. doi: 10.1128/AAC. 00319-11

Rowan, R., Moran, C., McCann, M., and Kavanagh, K. J. B. (2009). Use of Galleria mellonella larvae to evaluate the in vivo anti-fungal activity of [Ag2(mal)(phen)3]. Biometals 22, 461-467. doi: 10.1007/s10534-008-9182-3

Sang, Y., and Blecha, F. (2008). Antimicrobial peptides and bacteriocins: alternatives to traditional antibiotics. Anim. Health Res. Rev. 9, 227-235. doi: $10.1017 /$ S1466252308001497

Sangalli-Leite, F., Scorzoni, L., da Silva, J. D. F., de Oliveira, H. C., de Lacorte Singulani, J., Gullo, F. P., et al. (2016). Synergistic effect of pedalitin and amphotericin B against Cryptococcus neoformans by in vitro and in vivo evaluation. Int. J. Antimicrob. Agents 48, 504-511. doi: 10.1016/j.ijantimicag. 2016.07.025

Santos, J. R. A., Ribeiro, N. Q., Bastos, R. W., Holanda, R. A., Silva, L. C., Queiroz, E. R., et al. (2017). High-dose fluconazole in combination with amphotericin B is more efficient than monotherapy in murine model of cryptococcosis. Sci. Rep. 7:4661. doi: 10.1038/s41598-017-04588-7

Sathoff, A. E., and Samac, D. A. (2019). Antibacterial activity of plant defensins. Mol. Plant Microbe Interact. 32, 507-514. doi: 10.1094/mpmi-08-18-0229-cr

Scandalios, J. G. (2002). The rise of ROS. Trends Biochem. Sci. 27, 483-486. doi: 10.1016/S0968-0004(02)02170-9

Scarsini, M., Tomasinsig, L., Arzese, A., D’Este, F., Oro, D., and Skerlavaj, B. (2015). Antifungal activity of cathelicidin peptides against planktonic and biofilm cultures of Candida species isolated from vaginal infections. Peptides 71, 211-221. doi: 10.1016/j.peptides.2015.07.023

Segal, E., and Frenkel, M. J. (2018). Experimental in vivo models of candidiasis. J. Fungi 21:E21. doi: 10.3390/jof 4010021

Shafee, T. M., Lay, F. T., Hulett, M. D., and Anderson, M. A. (2016). The defensins consist of two independent, convergent protein superfamilies. Mol. Biol. Evol. 33, 2345-2356. doi: 10.1093/molbev/msw106

Shibata, N., Ichikawa, T., Tojo, M., Takahashi, M., Ito, N., Okubo, Y., et al. (1985). Immunochemical study on the mannans of Candida albicans NIH A207, NIH B-792, and J-1012 strains prepared by fractional precipitation with cetyltrimethylammonium bromide. Arch. Biochem. Biophys. 243, 338-348. doi: 10.1016/0003-9861(85)90511-9

Singulani, J. L., Scorzoni, L., Gomes, P. C., Nazaré, A. C., Polaquini, C. R., Regasini, L. O., et al. (2017). Activity of gallic acid and its ester derivatives in Caenorhabditis elegans and zebrafish (Danio rerio) models. Future Med. Chem. 9, 1863-1872. doi: 10.4155/fmc-2017-0096

Souza, A. C. R., Fuchs, B. B., Pinhati, H. M., Siqueira, R. A., Hagen, F., Meis, J. F., et al. (2015). Candida parapsilosis resistance to fluconazole: molecular mechanisms and in vivo impact in infected Galleria mellonella larvae. Antimicrob. Agents Chemoter. 59, 6581-6587. doi: 10.1128/AAC.011 $77-15$

Souza, B. M., Mendes, M. A., Santos, L. D., Marques, M. R., César, L. M., Almeida, R. N., et al. (2005). Structural and functional characterization of two novel peptide toxins isolated from the venom of the social wasp Polybia paulista. Peptides 26, 2157-2164. doi: 10.1016/j.peptides.2005.04.026

Subbanna, A. R. N. S., Chandrashekara, C., Stanley, J., Mishra, K. K., Mishra, P. K., and Pattanayak, A. (2019). Bio-efficacy of chitinolytic Bacillus thuringiensis isolates native to northwestern Indian Himalayas and their synergistic toxicity with selected insecticides. Pest. Biochem. Physiol. 158, 166-174. doi: 10.1016/j. pestbp.2019.05.005

Subramenium, G. A., Swetha, T. K., Iyer, P. M., Balamurugan, K., and Pandian, S. K. (2018). 5-hydroxymethyl-2-furaldehyde from marine bacterium Bacillus subtilis inhibits biofilm and virulence of Candida albicans. Am. J. Microbiol. Res. 207, 19-32. doi: 10.1016/j.micres.2017.11.002

Sun, J. N., Li, W., Jang, W. S., Nayyar, N., Sutton, M. D., and Edgerton, M. (2008). Uptake of the antifungal cationic peptide Histatin 5 by Candida albicans Ssa2p 
requires binding to non-conventional sites within the ATPase domain. Mol. Microbiol. 70, 1246-1260. doi: 10.1111/j.1365-2958.2008.06480.x

Sun, L., Liao, K., and Hang, C. J. P. (2018). Caffeic acid phenethyl ester synergistically enhances the antifungal activity of fluconazole against resistant Candida albicans. Phytomedicine 40, 55-58. doi: 10.1016/j.phymed.2017.12.033

Sung, W. S., Lee, J., and Lee, D. G. (2008). Fungicidal effect and the mode of action of piscidin 2 derived from hybrid striped bass. Biochem. Biophys. Res. Commun. 371, 551-555. doi: 10.1016/j.bbrc.2008.04.107

Swe, P. M., Heng, N. C., Ting, Y.-T., Baird, H. J., Carne, A., Tauch, A., et al. (2007). ef1097 and ypkK encode enterococcin V583 and corynicin JK, members of a new family of antimicrobial proteins (bacteriocins) with modular structure from Gram-positive bacteria. Microbiology 153, 3218-3227. doi: 10.1099/mic.0. 2007/010777-0

Szyk, A., Wu, Z., Tucker, K., Yang, D., Lu, W., and Lubkowski, J. (2006). Crystal structures of human $\alpha$-defensins HNP4, HD5, and HD6. Protein Sci. 15, 2749-2760. doi: 10.1110/ps.062336606

Tan, L., Bai, L., Wang, L., He, L., Li, G., Du, W., et al. (2018). Antifungal activity of spider venom-derived peptide lycosin-I against Candida tropicalis. Microbiol. Res. 216, 120-128. doi: 10.1016/j.micres.2018.08.012

Tati, S., Li, R., Puri, S., Kumar, R., Davidow, P., and Edgerton, M. (2014). Histatin 5 -spermidine conjugates have enhanced fungicidal activity and efficacy as a topical therapeutic for oral candidiasis. Antimicrob. Agents Chemother. 58, 756-766. doi: 10.1128/AAC.01851-13

Taylor, K., Barran, P. E., and Dorin, J. R. (2008). Structure-activity relationships in $\beta$-defensin peptides. J. Pept. Sci. 90, 1-7. doi: 10.1002/bip.20900

Thangamani, S., Eldesouky, H. E., Mohammad, H., Pascuzzi, P. E., Avramova, L., Hazbun, T. R., et al. (2017). Ebselen exerts antifungal activity by regulating glutathione (GSH) and reactive oxygen species (ROS) production in fungal cells. Biochim. Biophys. Acta Gen. Subj. 1861, 3002-3010. doi: 10.1016/j.bbagen. 2016.09.029

Thevissen, K., Kristensen, H. H., Thomma, B. P., Cammue, B. P., and Francois, I. E. (2007). Therapeutic potential of antifungal plant and insect defensins. Drug Discov. Today 12, 966-971. doi: 10.1016/j.drudis.2007.07.016

Thomma, B. P., Cammue, B. P., and Thevissen, K. (2002). Plant defensins. Planta 216, 193-202. doi: 10.1007/s00425-002-0902-6

Troxler, R. F., Offner, G. D., Xu, T., Vanderspek, J. C., and Oppenheim, F. G. (1990). Structural relationship between human salivary histatins. J. Dent. Res. 69, 2-6. doi: 10.1177/00220345900690010101

Tsai, H., and Bobek, L. A. (1998). Human salivary histatins: promising anti-fungal therapeutic agents. Crit. Rev. Oral Biol. Med. 9, 480-497.

Tsai, P. W., Yang, C. Y., Chang, H. T., and Lan, C. Y. (2011). Human antimicrobial peptide LL-37 inhibits adhesion of Candida albicans by interacting with yeast cell-wall carbohydrates. PLoS One 6:e17755. doi: 10.1371/journal.pone.001 7755

Uchida, R., Namiguchi, S., Ishijima, H., and Tomoda, H. (2016). Therapeutic effects of three trichothecenes in the silkworm infection assay with Candida albicans. Drug Discov. Ther. 10, 44-48. doi: 10.5582/ddt.2016.01013

Uppuluri, P., Chaturvedi, A. K., Srinivasan, A., Banerjee, M., Ramasubramaniam, A. K., Köhler, J. R., et al. (2010). Dispersion as an important step in the Candida albicans biofilm developmental cycle. PLoS Pathog. 6:e1000828. doi: 10.1371/ journal.ppat.1000828

van der Weerden, N. L., Hancock, R. E., and Anderson, M. A. (2010). Permeabilization of fungal hyphae by the plant defensin NaD1 occurs through a cell wall-dependent process. J. Biol. Chem. 285, 37513-37520. doi: 10.1074/jbc. M110.134882

Vriens, K., Cools, T. L., Harvey, P. J., Craik, D. J., Braem, A., Vleugels, J., et al. (2016). The radish defensins RsAFP1 and RsAFP2 act synergistically with caspofungin against Candida albicans biofilms. Peptides 75, 71-79. doi: 10.1016/ j.peptides.2015.11.001
Vriens, K., Cools, T. L., Harvey, P. J., Craik, D. J., Spincemaille, P., Cassiman, D., et al. (2015). Synergistic activity of the plant defensin HsAFP1 and caspofungin against Candida albicans biofilms and planktonic cultures. PLoS One 10:e0132701. doi: 10.1371/journal.pone.0132701

Walsh, T. J., Garrett, K., Feurerstein, E., Girton, M., Allende, M., Bacher, J., et al. (1995). Therapeutic monitoring of experimental invasive pulmonary aspergillosis by ultrafast computerized tomography, a novel, noninvasive method for measuring responses to antifungal therapy. Antimicrob. Agents Chemother. 39, 1065-1069. doi: 10.1128/AAC.39.5.1065

Wang, K., Dang, W., Xie, J., Zhu, R., Sun, M., Jia, F., et al. (2015). Antimicrobial peptide protonectin disturbs the membrane integrity and induces ROS production in yeast cells. Biochim. Biophys. Acta Biomembr. 1848, 2365-2373. doi: 10.1016/j.bbamem.2015.07.008

Wang, K., Yan, J., Dang, W., Xie, J., Yan, B., Yan, W., et al. (2014). Dual antifungal properties of cationic antimicrobial peptides polybia-MPI: membrane integrity disruption and inhibition of biofilm formation. Peptides 56, 22-29. doi: 10.1016/ j.peptides.2014.03.005

Wiederhold, N. P., Najvar, L. K., Matsumoto, S., Bocanegra, R. A., Herrera, M. L., Wickes, B. L., et al. (2015). Efficacy of the investigational echinocandin ASP9726 in a guinea pig model of invasive pulmonary aspergillosis. Antimicrob. Agents Chemother. 59, 2875-2881. doi: 10.1128/AAC.04857-14

Wu, H., Liu, S., Wiradharma, N., Ong, Z. Y., Li, Y., Yang, Y. Y., et al. (2017). Short synthetic $\alpha$-helical-forming peptide amphiphiles for fungal keratitis treatment in vivo. Adv. Healthc. Mater. 6, 1-7. doi: 10.1002/adhm.201600777

Wu, H., Ong, Z. Y., Liu, S., Li, Y., Wiradharma, N., Yang, Y. Y., et al. (2015). Synthetic $\beta$-sheet forming peptide amphiphiles for treatment of fungal keratitis. Biomaterials 43, 44-49. doi: 10.1016/j.biomaterials.2014.11.052

Young-Speirs, M., Drouin, D., Cavalcante, P. A., Barkema, H. W., and Cobo, E. R. (2018). Host defense cathelicidins in cattle: types, production, bioactive functions and potential therapeutic and diagnostic applications. Int. J. Antimicrob. Agents 51, 813-821. doi: 10.1016/j.ijantimicag.2018.02.006

Yu, H., Liu, X., Wang, C., Qiao, X., Wu, S., Wang, H., et al. (2016). Assessing the potential of four cathelicidins for the management of mouse candidiasis and Candida albicans biofilms. Biochimie 121, 268-277. doi: 10.1016/j.biochi.2015. 11.028

Zanette, R. A., and Kontoyiannis, D. P. (2013). Paradoxical effect to caspofungin in Candida species does not confer survival advantage in a Drosophila model of candidiasis. J. Virulence 4, 497-498. doi: 10.1016/j.biochi.2015.11.028

Zanetti, M. (2004). Cathelicidins, multifunctional peptides of the innate immunity. J. Leukoc. Biol. 75, 39-48. doi: 10.1189/jlb.0403147

Zanetti, M., Gennaro, R., and Romeo, D. (1995). Cathelicidins: a novel protein family with a common proregion and a variable C-terminal antimicrobial domain. FEBS Lett. 374, 1-5. doi: 10.1016/0014-5793(95)01050-O

Zhao, J., Cheng, Y., Song, X., Wang, C., Su, G., and Liu, Z. (2015). A comparative treatment study of intravitreal voriconazole and liposomal amphotericin B in an Aspergillus fumigatus endophthalmitis model. Invest. Ophthalmol. Vis. Sci. 56, 7369-7376. doi: 10.1167/iovs.15-17266

Conflict of Interest: The authors declare that the research was conducted in the absence of any commercial or financial relationships that could be construed as a potential conflict of interest.

Copyright (c) 2019 Oshiro, Rodrigues, Monges, Cardoso and Franco. This is an openaccess article distributed under the terms of the Creative Commons Attribution License (CC BY). The use, distribution or reproduction in other forums is permitted, provided the original author(s) and the copyright owner(s) are credited and that the original publication in this journal is cited, in accordance with accepted academic practice. No use, distribution or reproduction is permitted which does not comply with these terms. 